\title{
Engineering of human lactoferrin for improved anticancer activity
}

\author{
Yu Pan, ${ }^{\ddagger 1}$ Niying Chua, ${ }^{\ddagger, 2}$ Kaisheng Lim, ${ }^{1}$ Chun Loong Ho ${ }^{*}, 1$ \\ 1 Department of Biomedical Engineering, Southern University of Science and Technology; hejl@sustech.edu.cn \\ 2 School of Biological Sciences, Nanyang Technological University, 60 Nanyang Drive 637551. \\ $\ddagger$ These authors contributed equally. \\ * Correspondence: hejl@sustech.edu.cn.
}

\begin{tabular}{|c|c|c|}
\hline No & Title & Page \\
\hline 1 & Materials and methods & $S-3$ \\
\hline 2 & $\begin{array}{l}\text { Table S1: Real-time reverse transcription-polymerase chain reaction } \\
\text { (RT-PCR) primer sequence }\end{array}$ & $S-5$ \\
\hline 3 & Fig S1: Sequence and structure of full length lactoferrin and rtHLF4. & S-6 \\
\hline 4 & $\begin{array}{l}\text { Fig S2: Anticancer activity of lactoferrin and rtHLF4 in HGC27 human } \\
\text { gastric adeno-carcinoma cells. }\end{array}$ & S-7 \\
\hline 5 & $\begin{array}{l}\text { Fig S3: Anticancer activity of lactoferrin and rtHLF4 in AGS human } \\
\text { gastric adeno-carcinoma cells. }\end{array}$ & S-8 \\
\hline 6 & $\begin{array}{l}\text { Fig S4: Anticancer activity of lactoferrin and rtHLF4 in Caco2 human } \\
\text { colorectal adeno-carcinoma cells. }\end{array}$ & S-9 \\
\hline 7 & $\begin{array}{l}\text { Fig S5: Anticancer activity of lactoferrin and rtHLF4 in LoVo human } \\
\text { colorectal adeno-carcinoma cells. }\end{array}$ & $S-10$ \\
\hline 8 & $\begin{array}{l}\text { Fig S6: Anticancer activity of lactoferrin and rtHLF4 in HCT116 human } \\
\text { colorectal adenocarcinoma cells. }\end{array}$ & $S-11$ \\
\hline 9 & $\begin{array}{l}\text { Fig S7: Full length lactoferrin and rtHLF4 with different concentration } \\
\text { induce TAZ, GDF15, Bc12, Bax, Bak, p53, Caspase3 and Caspase } 8 \\
\text { gene expression and Western blot in MCF7 human breast } \\
\text { adenocarcinoma cells. }\end{array}$ & $\mathrm{S}-12$ \\
\hline 10 & $\begin{array}{l}\text { Fig S8: Full length lactoferrin and rtHLF4 with different concentration } \\
\text { induce TAZ, GDF15, Bc12, Bax, Bak, p53, Caspase } 3 \text { and Caspase } 8 \\
\text { gene expression and Western blot in HGC27 human gastric } \\
\text { adenocarcinoma cells. }\end{array}$ & S-16 \\
\hline 11 & $\begin{array}{l}\text { Fig S9: Full length lactoferrin and rtHLF4 with different concentration } \\
\text { induce TAZ, GDF15, Bc12, Bax, Bak, p53, Caspase } 3 \text { and Caspase8 }\end{array}$ & S-20 \\
\hline
\end{tabular}




\begin{tabular}{|c|l|c|}
\hline & $\begin{array}{l}\text { gene expression and Western blot in AGS human gastric } \\
\text { adenocarcinoma cells. }\end{array}$ & S-24 \\
\hline 12 & $\begin{array}{l}\text { Fig S10: Full length lactoferrin and rtHLF4 with different concentration } \\
\text { induce TAZ, GDF15, Bc12, Bax, Bak, p53, Caspase3 and Caspase8 } \\
\text { gene expression and Western blot in Caco2 human colorectal } \\
\text { adenocarcinoma cells. }\end{array}$ & S-28 \\
\hline 13 & $\begin{array}{l}\text { Fig S11: Full length lactoferrin and rtHLF4 with different concentration } \\
\text { induce TAZ, GDF15, Bc12, Bax, Bak, p53, Caspase3 and Caspase8 } \\
\text { gene expression and Western blot in LoVo human colorectal } \\
\text { adenocarcinoma cells. }\end{array}$ & $\begin{array}{l}\text { Fig S12: Full length lactoferrin and rtHLF4 with different concentration } \\
\text { induce TAZ, GDF15, Bcl2, Bax, Bak, p53, Caspase3 and Caspase8 gene } \\
\text { expression and Western blot in HCT116 human colorectal adenocarcinoma } \\
\text { cells. }\end{array}$ \\
\hline
\end{tabular}




\section{Materials and methods}

Materials. All culturing media ingredients were purchased from Oxoid, Macklin and Aladdin. Biochemical assay solutions were purchased from Aladdin, Dieckmann and Shanghai lingfeng chemical reagent co., Itd. Other chemicals used are specified in the methods below.

Peptic digestion of flHLF. flHLF was incubated with pepsin $(5 \mathrm{mg} / \mathrm{mL})$ and reaction buffer $(0.1 \mathrm{M}$ glycine-HCL, $\mathrm{pH} 3.0)$ for $3 \mathrm{hrs}$ at $37^{\circ} \mathrm{C}$. The reaction was terminated by putting the sample on ice and adjusting to $\mathrm{pH} 6.8$ using $\mathrm{NaOH}$.

Tryptic digestion of flHLF. flHLF was incubated with trypsin $(0.15 \mathrm{mg} / \mathrm{mL})$ and reaction buffer $(0.05 \mathrm{M}$ tris, $0.02 \mathrm{M} \mathrm{CaCl} 2, \mathrm{pH} 7.8)$ for $24 \mathrm{hrs}$ at $37^{\circ} \mathrm{C}$.

Isolation, characterization and cloning of fragments. These fragments were generated through protease (pepsin or trypsin) digestion of flHLF. The fragments were fractionated via size exclusion using a Superdex S75 column on a AKTA-pure system. Individual fractions were tested for the individual anticancer activities, where fractions containing improved anticancer activities were excised from SDS-PAGE and identified using MALDI-TOF Mass Spectrometry.

rtHLF4 was amplified by PCR from full length lactoferrin using primers.

rtHLF4_Fwd 5'-AAAAAAGCTAGCGAAGTTAAGACCAGTTGCTGC-'3

rtHLF4_Rev 5'-AAAAAACTCGAGCATCTGAAAGCACCAGTGTA-3'.

The PCR product was cloned to $\mathrm{pET} 28 \mathrm{~b}$ vector using restriction enzymes NheI and XhoI.

Protein purification. BL21 (DE3) transformed with plasmid pET28b-rtHLF4 were cultured in $37^{\circ} \mathrm{C}, 225 \mathrm{rpm}$ induced at $\mathrm{OD}_{600}=0.6$ with $0.5 \mathrm{mM}$ of Isopropyl $\beta$-D-1-thiogalactopyranoside (IPTG) and was expressed at $20^{\circ} \mathrm{C}, 160 \mathrm{rpm}$. Cells were harvested, resuspended in lysis buffer (50mM Tris-HCL, $300 \mathrm{mM} \mathrm{NaCl}, 10 \%$ glycerol, $3 \mu \mathrm{M} \beta$-Mercaptoethanol, pH7.5) and lysed using Emulsiflex C-3. Expressed rtHLF4 was purified via IMAC Ni-NTA purification followed by size exclusion chromatography (SEC) with Hi-Load Superdex 200 size exclusion column (GE).

Hemolytic assay. Fresh blood was collected from healthy human volunteers (aged between 25 40 years old, devoid of any non-steroidal anti-inflammatory drugs for 2 weeks prior) was mixed with equal volume of sterilized Alsever solution ( $2 \%$ dextrose, $0.8 \%$ sodium citrate, $0.5 \%$ citric acid and $0.42 \%$ sodium chloride). The blood was centrifuged for 5 minutes at $3000 \mathrm{rpm}$. Concentrated cell stock was prepared by resuspending cell pellets in isosaline $(0.9 \% \mathrm{w} / \mathrm{v} \mathrm{NaCl})$. Cell stock was diluted 10 -folds in isosaline to achieve working concentrations. Various concentrations of the rtHLF4/flHLF protein $(100 \mu \mathrm{M}, 10 \mu \mathrm{M}, 1 \mu \mathrm{M}, 0.1$ $\mu \mathrm{M}, 0.01 \mu \mathrm{M}, 0.001 \mu \mathrm{M}$ ) were prepared in protein buffer and to each concentration, $1 \mathrm{ml}$ phosphate buffer, $2 \mathrm{ml}$ hyposaline, and $0.5 \mathrm{ml} \mathrm{HRBC} \mathrm{(human} \mathrm{red} \mathrm{blood} \mathrm{cells)} \mathrm{suspension} \mathrm{were}$ added. The cell suspensions were incubated at $37^{\circ} \mathrm{C}$ for $30 \mathrm{~min}$ and centrifuged at $3000 \mathrm{rpm}$ for $20 \mathrm{~min}$. The hemoglobin content in the supernatant solution was estimated spectrophotometrically at $560 \mathrm{~nm}$. All experiments were conducted with the approval of the Institutional Review Board at the Southern University of Science and Technology, under the title of "Evaluation of the safety of therapeutic peptides by hemolysis" with approval number 2020 SYG096. 
Cell culture. All cell lines are from American Type Culture Collection (ATCC). MCF7 human breast adenocarcinoma cells, HGC27 human gastric adenocarcinoma cells, AGS human gastric adenocarcinoma cells, HCT116 human colon carcinoma cells, LoVo human colorectal adenocarcinoma cells, Caco2 human colorectal adenocarcinoma cells were used in this study. MCF7 cells were cultured in DMEM medium, HGC27 cells were cultured in RPMI-1640 medium, Caco2 cells were cultured in MEM medium, HCT116 cells were cultured in McCoy's 5A medium, and LoVo and AGS cells in Ham's F12 medium. All the cell culture media were purchased from Hyclone and supplemented with 1\% antibiotics (penicillin/streptomycin) and $10 \%$ fetal bovine serum (v/v). All cell cultures were maintained at $37^{\circ} \mathrm{C}$ in $5 \% \mathrm{CO}_{2}$.

Cell viability assay. Cells were seeded in 96 well plates and incubated with full length lactoferrin (flHLF) and rtHLF4 till $3 \mathrm{hrs}, 24 \mathrm{hrs}$, and $72 \mathrm{hrs}$ time points. The cell viability assay using CellTiter $96^{\circledR}$ Aqueous One Solution Kit (Promega, USA). Cell culture media was aspirated and the cells were washed with phosphate buffered saline (PBS) before incubating the cells with MTS for $1-4 \mathrm{hrs}$ at $37^{\circ} \mathrm{C}$ in $5 \% \mathrm{CO}_{2}$. Add $10 \%$ SDS to end the reaction. All wells were read at absorbance wavelength of $490 \mathrm{~nm}$.

Real-time reverse transcription-polymerase chain reaction (RT-PCR). RNA in six different cancer cells was extracted using Eastep® Super Total RNA Extraction Kit (Promega, UAS) as stated by manufacturer. For the synthesis of cDNA, $1 \mu$ g RNAs of each sample were reversed transcribed to cDNA using GoScript ${ }^{\mathrm{TM}}$ Reverse Transcription System (Promega, USA), according to the manufacturer's instructions. Subsequently, 20ng cDNAs were mixed with specific primers and quantitative PCR (qPCR) was performed by using FasStart Universal SYBR Green Master (ROX) (Promega) using ABI StepOne Plus Realtime PCR System (Applied Biosystems, Foster City, CA, USA). The primer sequence used in this study were provided in Table S1. Data were analyzed using the classic $2^{-\Delta \Delta C t}$ method and were normalized with GAPDH.

Western blot. Protein expression levels were analyzed by western blot. Cells were seeded in 6 well plates and incubated with target protein fragment for $3 \mathrm{hrs}, 24 \mathrm{hrs}$ and $72 \mathrm{hrs}$. Cells were washed in phosphate buffered saline (PBS) and lysed in RIPA buffer $(0.6057 \mathrm{~g}$ Tris base, $0.877 \mathrm{~g} \mathrm{NaCl}, 10 \mathrm{ml}$ Nonident P-40, $5 \mathrm{ml}$ 10\% Na-deoxycholate, $1 \mathrm{ml} 10 \%$ sodium dodecyl sulphate, $\mathrm{PH}$ set to 7.5 , adjusted to $100 \mathrm{ml}$ with $\mathrm{H}_{2} \mathrm{O}$ ) for 30 min before centrifugation and supernatant collection. Subsequently, $20 \mu \mathrm{L}$ of whole cell extracts were resolved by sodium dodecyl sulfate-polyacrylamide gel electrophoresis (SDS-PAGE) and transferred to polyvinylidene difluoride (PVDF) membranes. The membranes were blocked with 5\% nonfat-milk and then incubated within primary antibodies (Abcam, UK): GAPDH, TAZ, GDF15, Bcl2, Bax, Bak, p53, Caspase 3 and Caspase 8 at $4^{\circ} \mathrm{C}$ overnight. The membranes were then incubated with the secondary antibodies (Abcam, UK) for $2 \mathrm{~h}$. Blots were visualized by enhanced chemiluminescence (ECL) method.

Statistical analysis. All data were presented from three independent experiments. Statistical analysis was performed by using SigmaPlot and GraphPad software to calculate the P-values to determine the statistical significance of the observed differences. The results are indicated by the asterisks $\left(*, \mathrm{P}<0.05 ;{ }^{* *}, \mathrm{P}<0.01 ;{ }^{* * *}, \mathrm{P}<0.001\right)$. 
Table S1: Real-time reverse transcription-polymerase chain reaction (RT-PCR) primer sequence

\begin{tabular}{|c|c|c|c|}
\hline Gene & & Primer sequence & Product length \\
\hline \multirow{2}{*}{ GAPDH } & sense $\left(5^{\prime}-3^{\prime}\right)$ & CAGGAGGCATTGCTGATGAT & \multirow{2}{*}{$138 \mathrm{bp}$} \\
\hline & antisense $\left(5^{\prime}-3^{\prime}\right)$ & GAAGGCTGGGGCTCATTT & \\
\hline \multirow{2}{*}{ TAZ } & sense $\left(5^{\prime}-3^{\prime}\right)$ & CGGCTGTGGAGATGCGGAAAG & \multirow{2}{*}{ 98bp } \\
\hline & antisense $\left(5^{\prime}-3^{\prime}\right)$ & AGGCTGGAGGTGGTTGTGGAG & \\
\hline \multirow{2}{*}{ GDF15 } & sense $\left(5^{\prime}-3^{\prime}\right)$ & CTGGTGTTGCTGGTGCTCTCG & \multirow{2}{*}{$117 \mathrm{bp}$} \\
\hline & antisense $\left(5^{\prime}-3^{\prime}\right)$ & TCGGAATCTGGAGTCTTCGGAGTG & \\
\hline \multirow{2}{*}{ Bcl2 } & sense $\left(5^{\prime}-3^{\prime}\right)$ & TACGAGTGGGATGCGGGAGATG & \multirow{2}{*}{ 80bp } \\
\hline & antisense $\left(5^{\prime}-3^{\prime}\right)$ & CCGGGCTGGGAGGAGAAGATG & \\
\hline \multirow{2}{*}{ Bax } & sense $\left(5^{\prime}-3^{\prime}\right)$ & GATTGCCGCCGTGGACACAG & \multirow{2}{*}{$87 \mathrm{bp}$} \\
\hline & antisense $\left(5^{\prime}-3^{\prime}\right)$ & CCCCAGTTGAAGTTGCCGTCAG & \\
\hline \multirow{2}{*}{ Bak } & sense $\left(5^{\prime}-3^{\prime}\right)$ & GGACGACATCAACCGACGCTATG & \multirow{2}{*}{$111 \mathrm{bp}$} \\
\hline & antisense $\left(5^{\prime}-3^{\prime}\right)$ & AACAGGCTGGTGGCAATCTTGG & \\
\hline \multirow{2}{*}{ P53 } & sense $\left(5^{\prime}-3^{\prime}\right)$ & GTTGGTCGGTGGGTTGGTAGTTTC & \multirow{2}{*}{$150 \mathrm{bp}$} \\
\hline & antisense (5'-3') & CAGGGTGTGGGATGGGGTGAG & \\
\hline \multirow{2}{*}{ Caspase 3} & sense $\left(5^{\prime}-3^{\prime}\right)$ & CAGGGCACACAGGACTTGGAAAG & \multirow{2}{*}{$107 \mathrm{bp}$} \\
\hline & antisense ( $\left.5^{\prime}-3^{\prime}\right)$ & AGGCCAGGAGCAGAGCACAG & \\
\hline \multirow{2}{*}{ Caspase8 } & sense $\left(5^{\prime}-3^{\prime}\right)$ & CCTGACAAGCGGTGATGTGGAC & \multirow{2}{*}{$139 \mathrm{bp}$} \\
\hline & antisense (5'-3') & GAGCAGCTCATCCTCAAGCAATCC & \\
\hline
\end{tabular}


a)

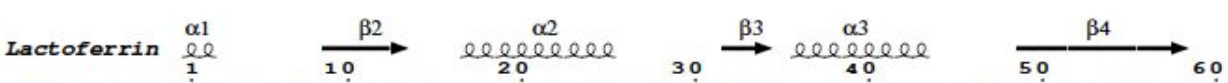

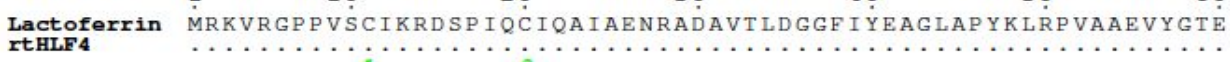

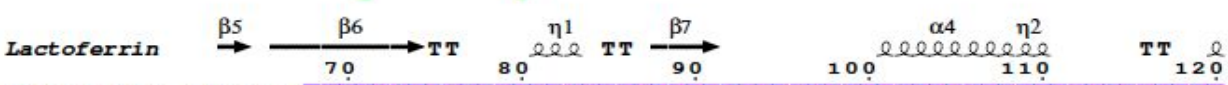

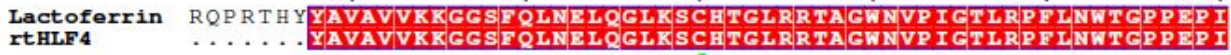

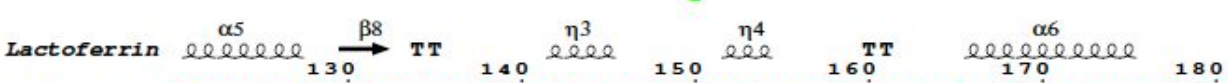

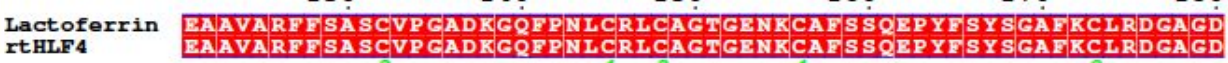

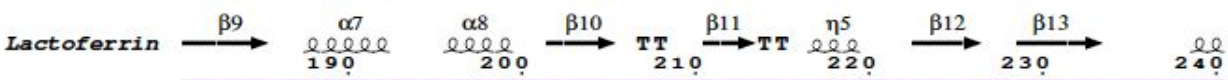
$\begin{array}{ll}\text { Lactoferrin } & \text { VAFIRESTVFEDLSDEAERDEYELLCPDNTRKPVDKFKDCHLARVPSHAVVARSVINGED } \\ \text { rtHLF4 } & \text { VAFIRESTVFEDLSDEAERDEYELLCPDNTRKPVDKFKDCHLARVPSHAVVARSVINGKED }\end{array}$

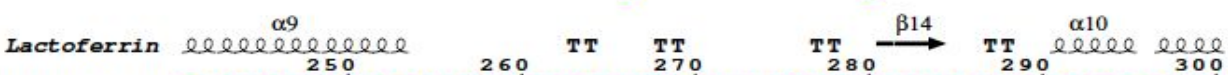
Lactoferrin ATWNLLROAQEKTGKDKSPKFQLFGSPSGQKDLLFKDSAIGFSRVPPRIDSGLYLGSGY
rtHLF4

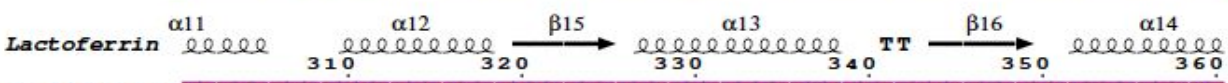
Lactoferrin TAIQNLRKSEIEVAARRARV WCAVGEQELRKCNQWSGLSEGSVTCSSASTTEDCIALVL
rtHLF4

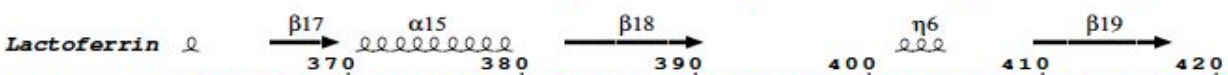
Lactoferrin
TtHLFA

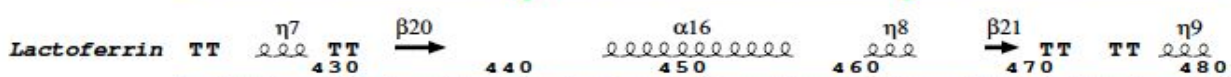
Lactoferrin TSLTWNSVKGKKSCHTAVDR TA GWN IPKGLIFNOTGSCKFDEYFSQSCAPGSDPRSNLCA
rtHLF4

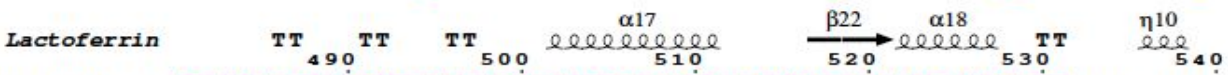
Lactoferrin LCIGDEQGENKCVPNSNERYYGYTGAFRCLAENAGDVAFVKDVTVLQNTDGNNNE AW AKD

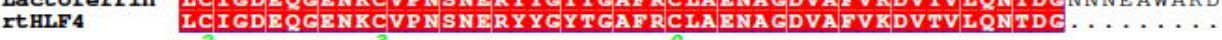

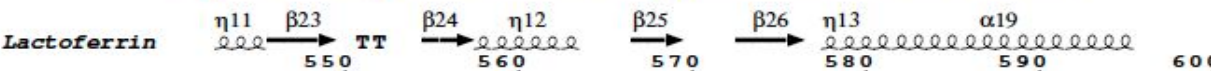
Lactoferrin LKLADFALLCLDGKRKPVTEARSCHLAMAPNHAVVSRMDKVERLKQVLLHQQAKFGRNGS

b)

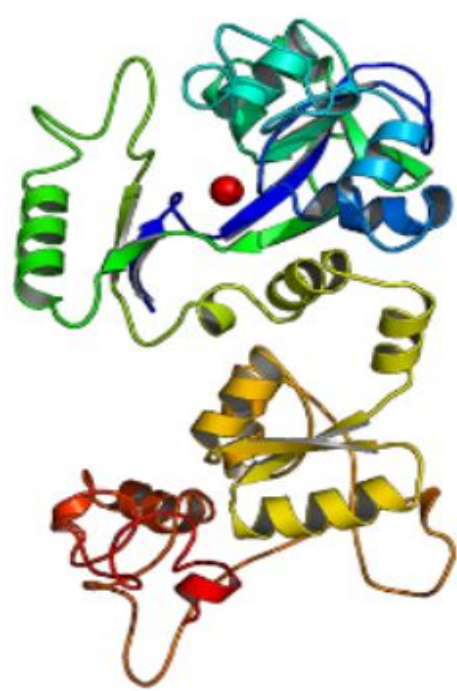

c)

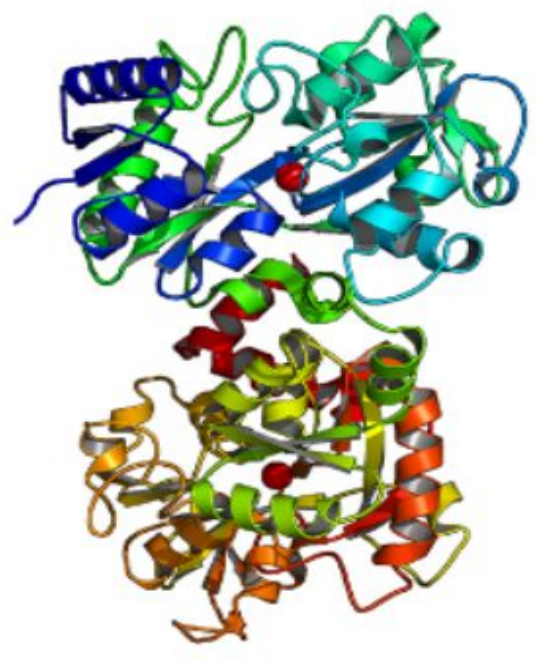

Fig S1: Sequence and structure of full length lactoferrin and rtHLF4. (a) Sequence alignment of flHLF and rtHLF4. (b) Modeled rtHLF4 structure. (c) Crystal structure of lactoferrin (PDB ID: 1B0L). 
a)

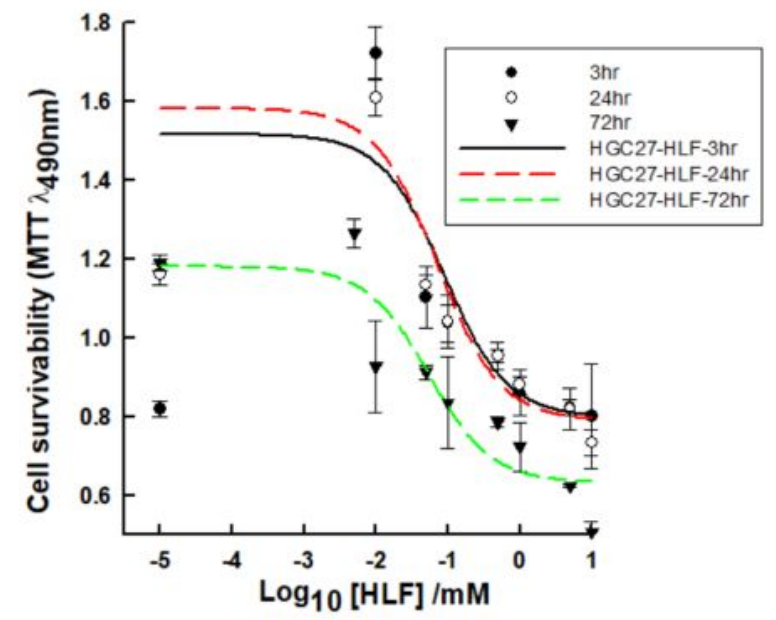

b)

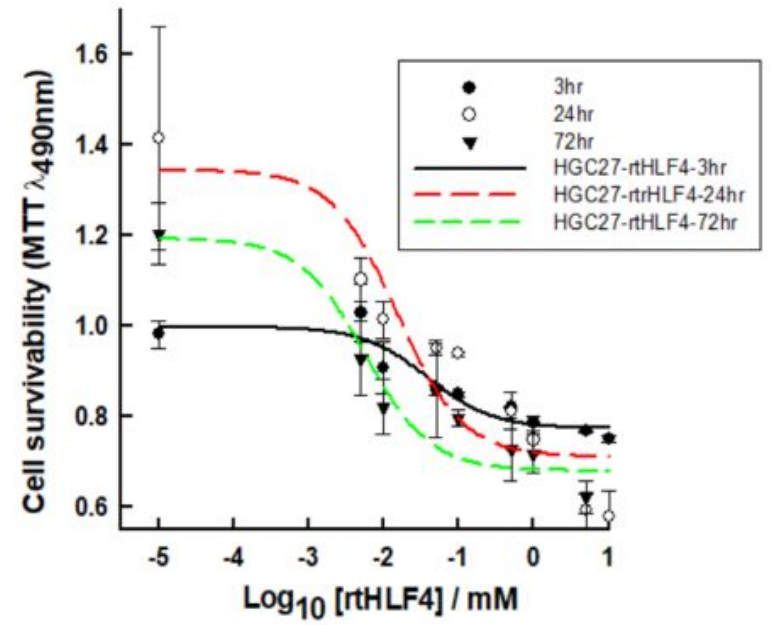

c)

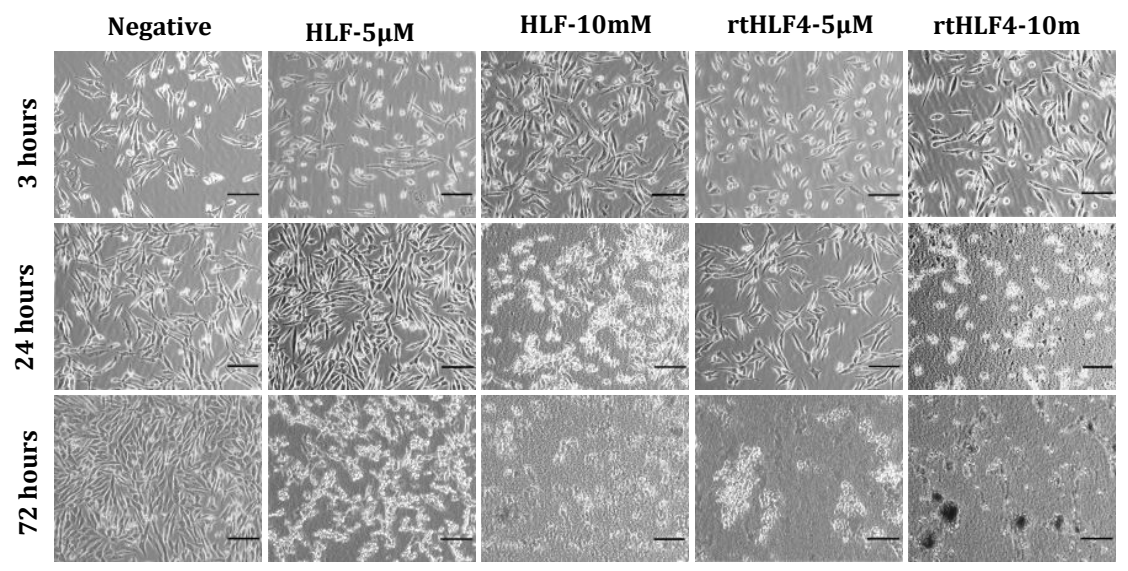

Fig S2: Anticancer activity of lactoferrin and rtHLF4 in HGC27 human gastric adenocarcinoma cells. Dose-response of HGC27 against varying concentration of (a) full length lactoferrin and (b) rtHLF4. (c) Cell morphology of HGC27 cell lines treated with varying concentration of full length lactoferrin and rtHLF4 (bar=100 $\mu \mathrm{m})$. 
a)

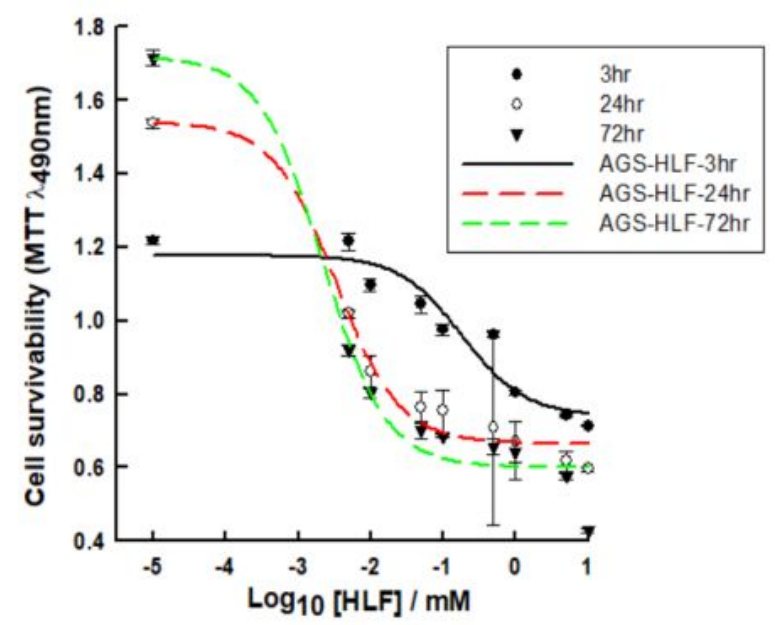

b)

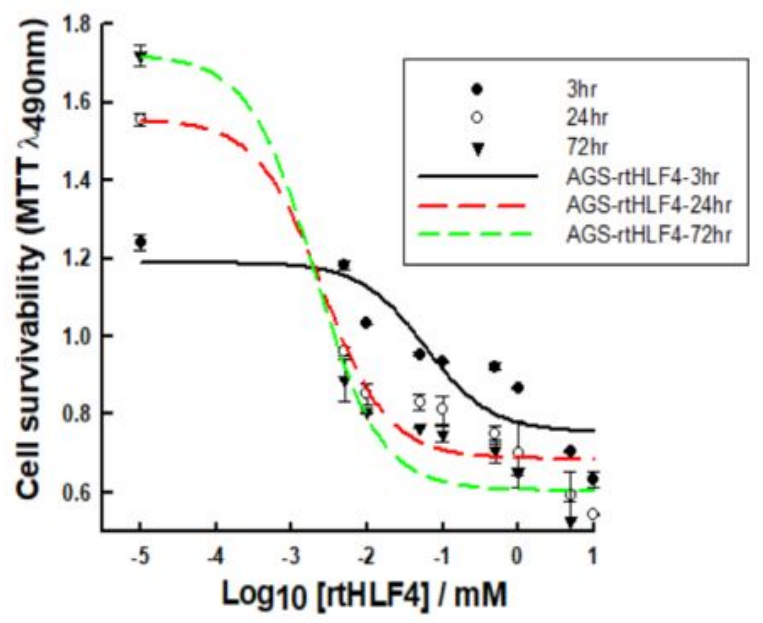

c)

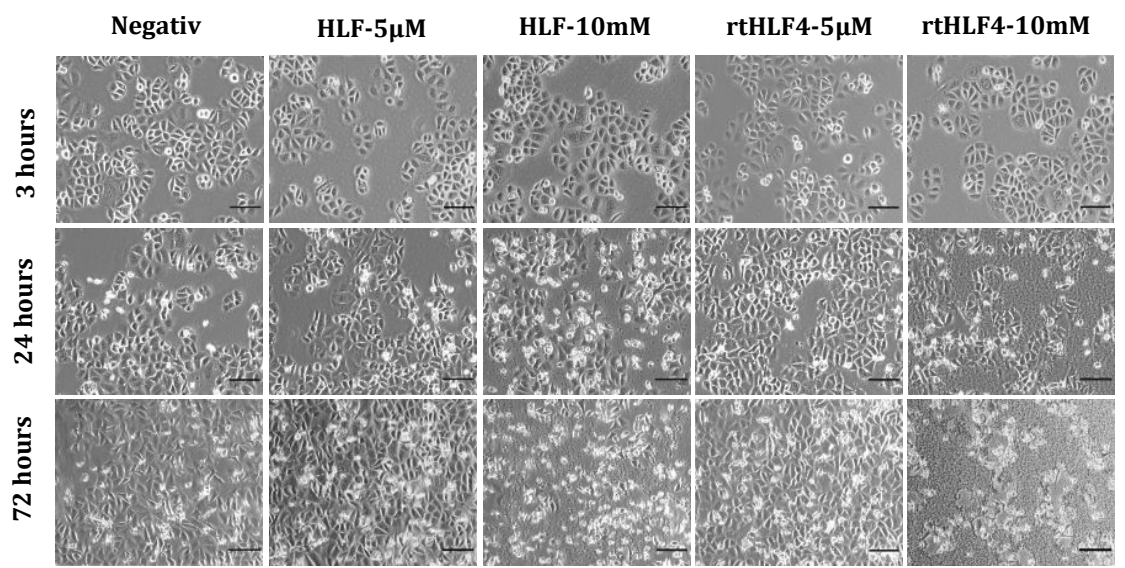

Fig S3: Anticancer activity of lactoferrin and rtHLF4 in AGS human gastric adenocarcinoma cells. Dose-response of AGS against varying concentration of (a) full length lactoferrin and (b) rtHLF4. (c) Cell morphology of AGS cell lines treated with varying concentration of full length lactoferrin and rtHLF4 (bar $=100 \mu \mathrm{m})$. 
a)

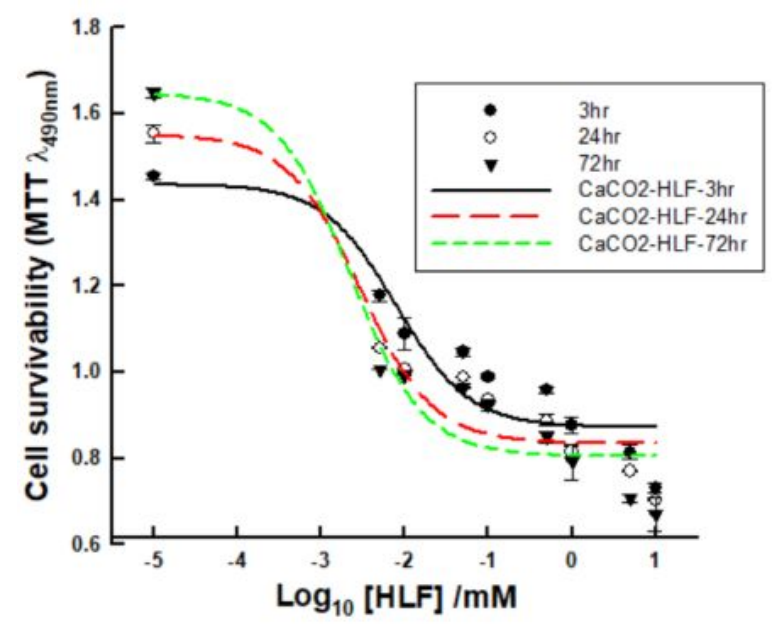

b)

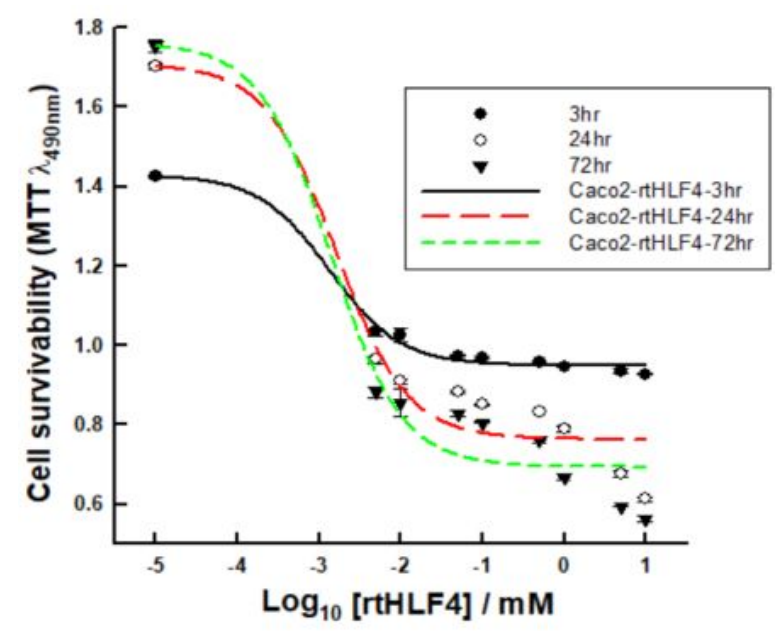

c)

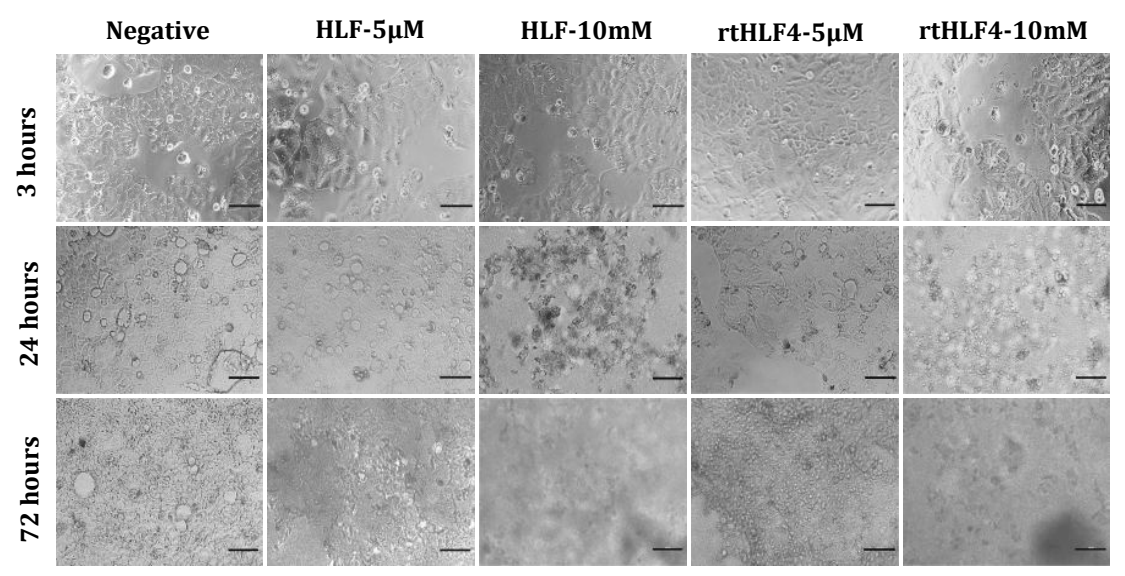

Fig S4: Anticancer activity of lactoferrin and rtHLF4 in Caco2 human colorectal adenocarcinoma cells. Dose-response of Caco2 against varying concentration of (a) full length lactoferrin and (b) rtHLF4. (c) Cell morphology of Caco2 cell lines treated with varying concentration of full length lactoferrin and rtHLF4 (bar $=100 \mu \mathrm{m})$. 
a)

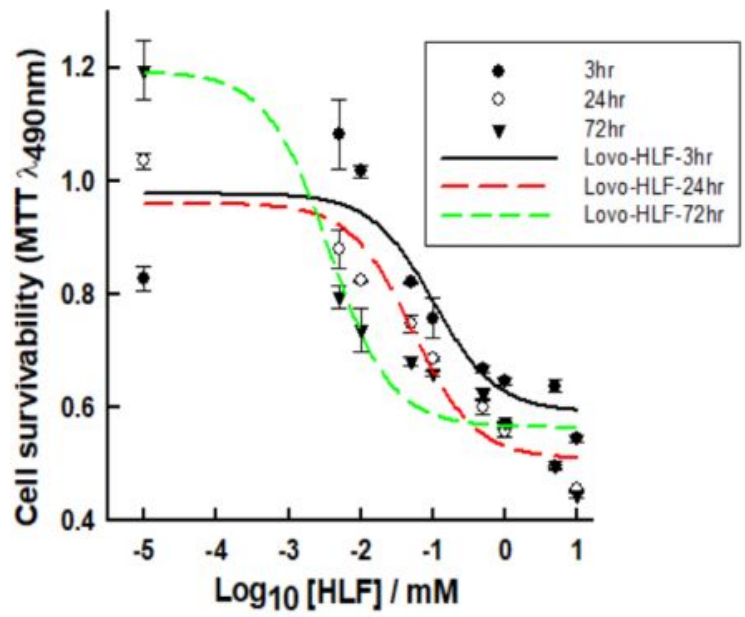

b)

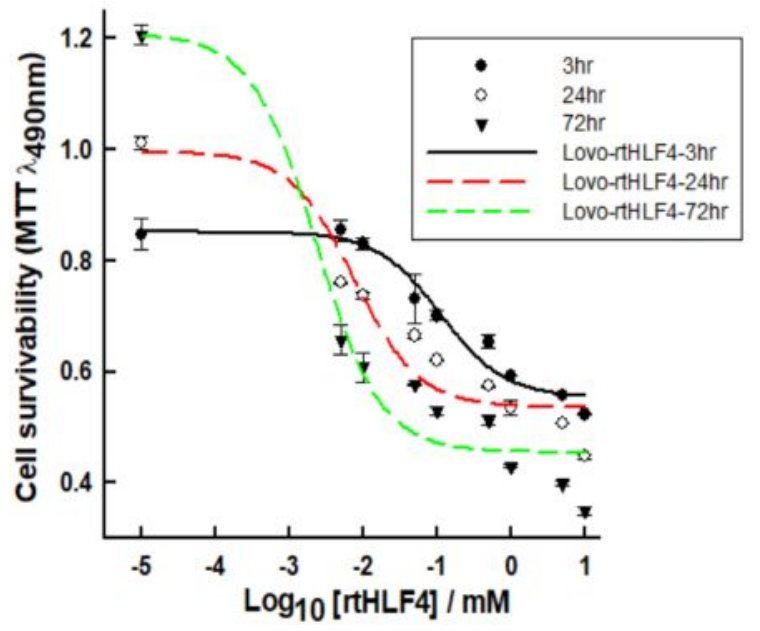

c)

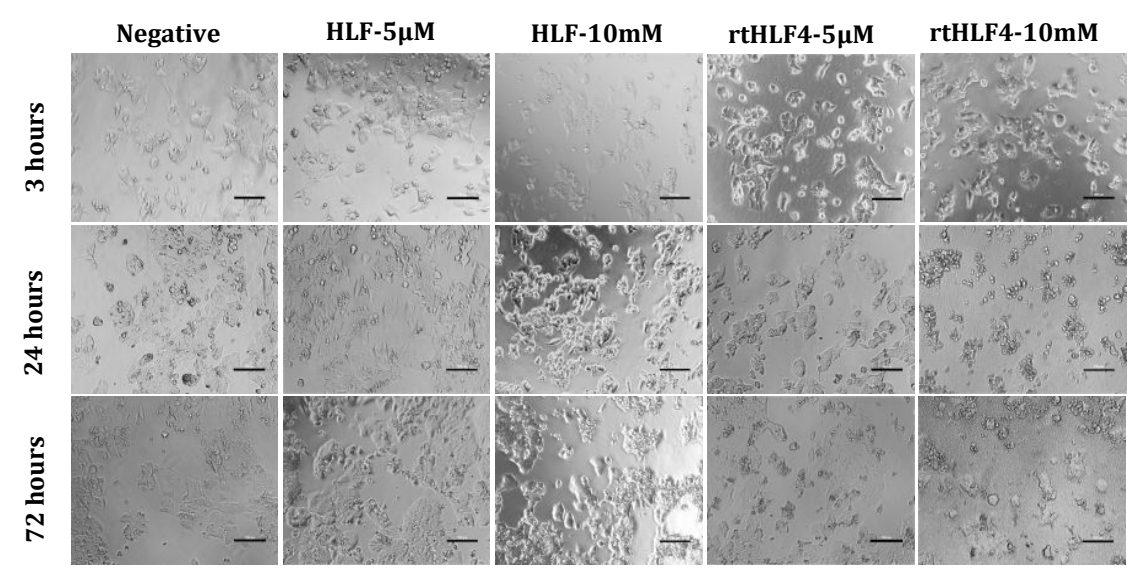

Fig S5: Anticancer activity of lactoferrin and rtHLF4 in LoVo human colorectal adenocarcinoma cells. Dose-response of LoVo against varying concentration of (a) full length lactoferrin and (b) rtHLF4. (c) Cell morphology of LoVo cell lines treated with varying concentration of full length lactoferrin and rtHLF4 (bar=100 $\mu \mathrm{m})$. 
a)

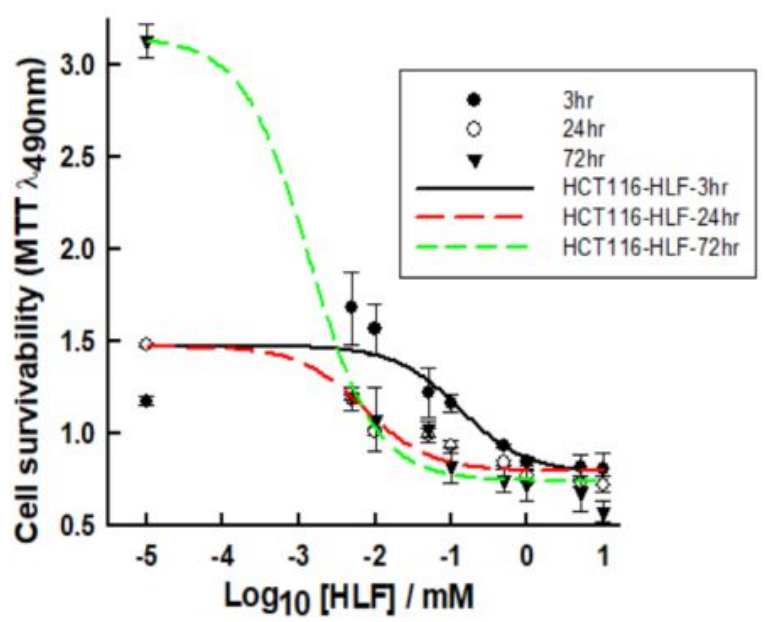

b)

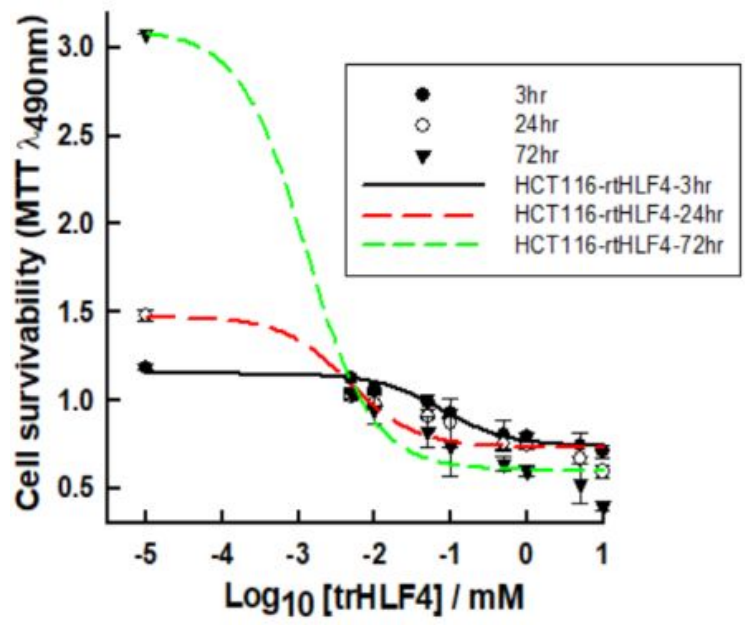

c)

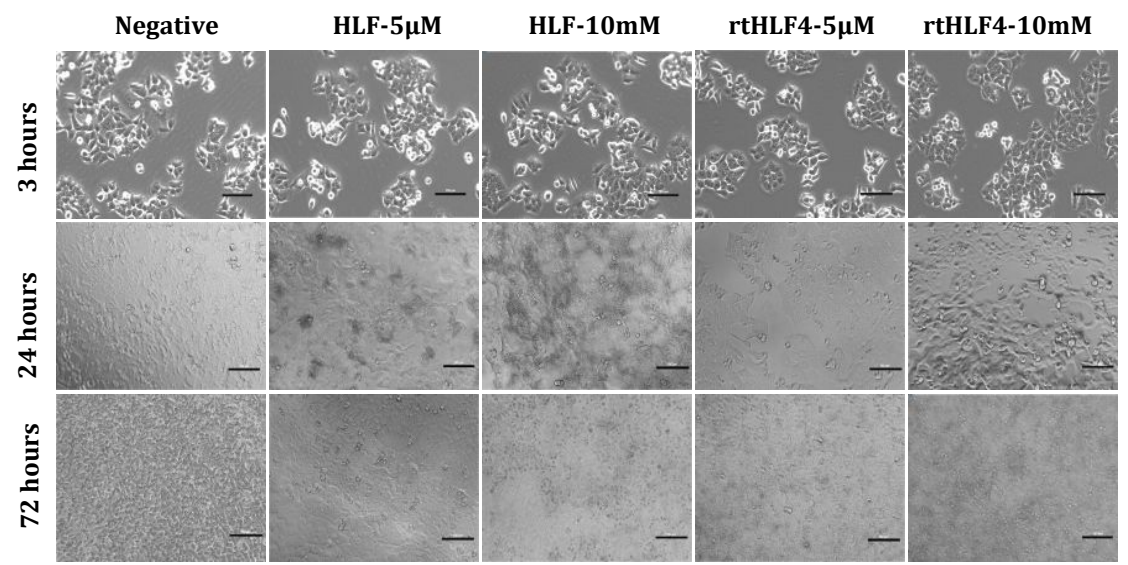

Fig S6: Anticancer activity of lactoferrin and rtHLF4 in HCT116 human colorectal adenocarcinoma cells. Dose-response of HCT116 against varying concentration of (a) full length lactoferrin and (b) rtHLF4. (c) Cell morphology of HCT116 cell lines treated with varying concentration of full length lactoferrin and rtHLF4 (bar=100 $\mu \mathrm{m})$. 
TAZ
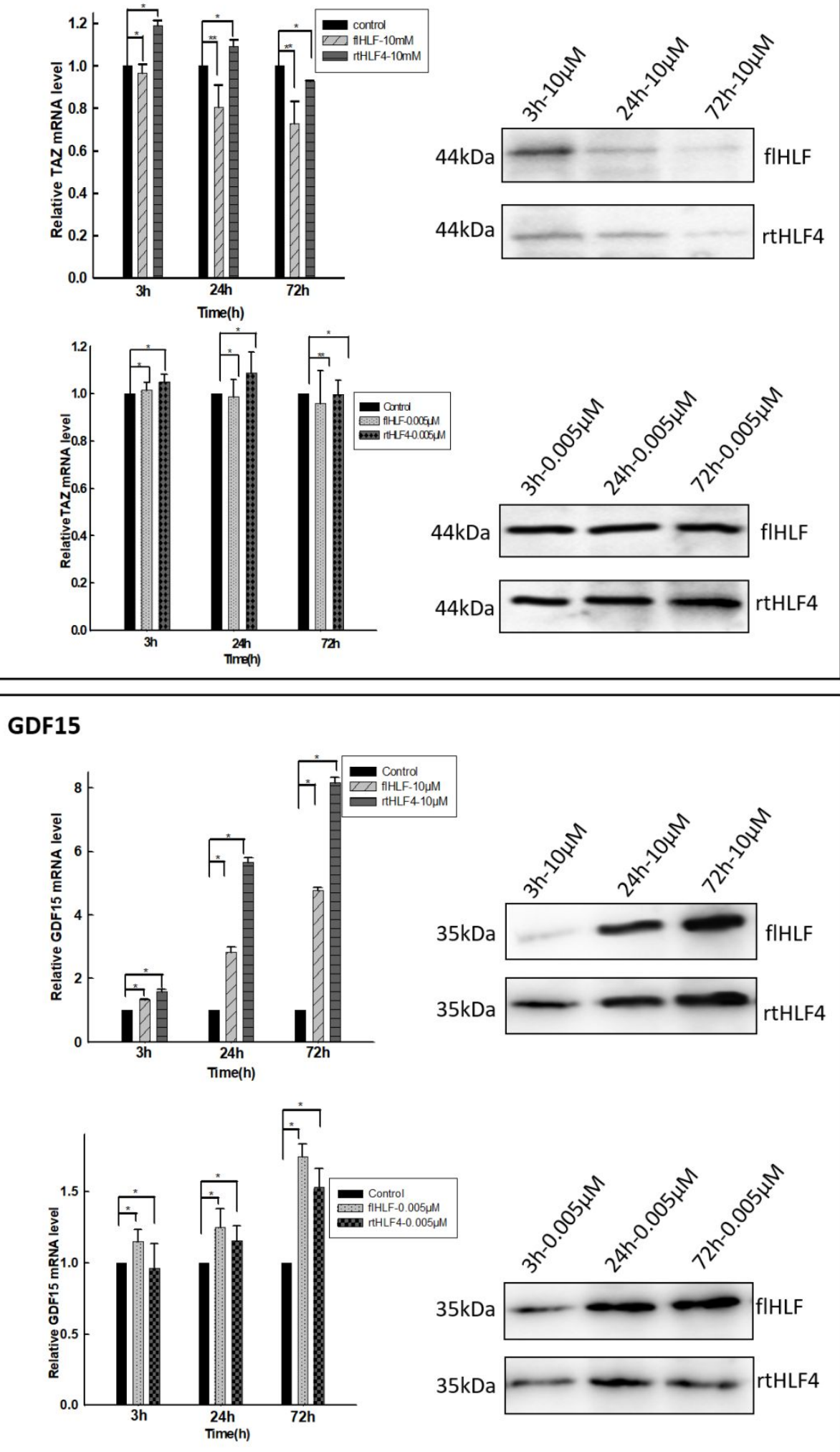

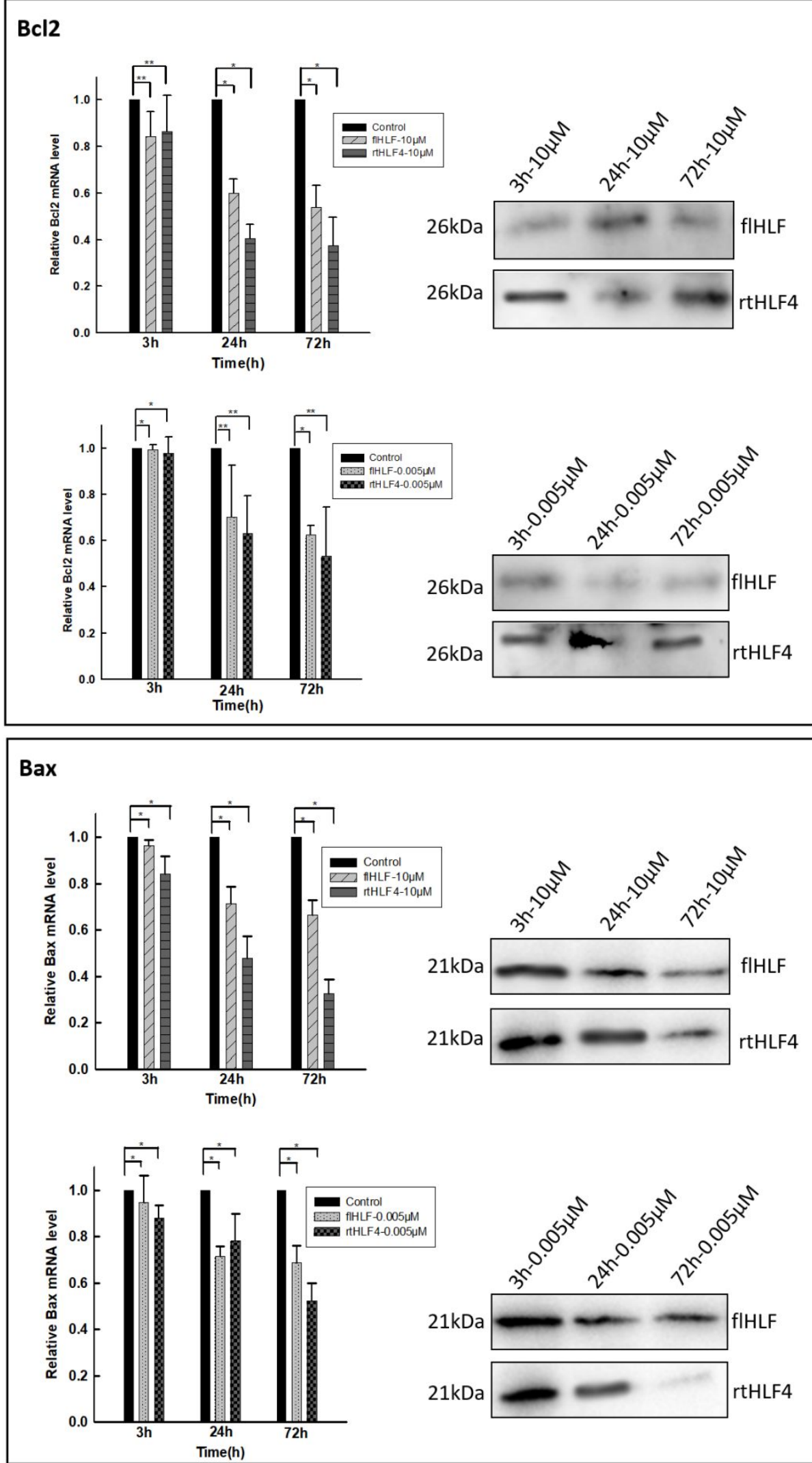

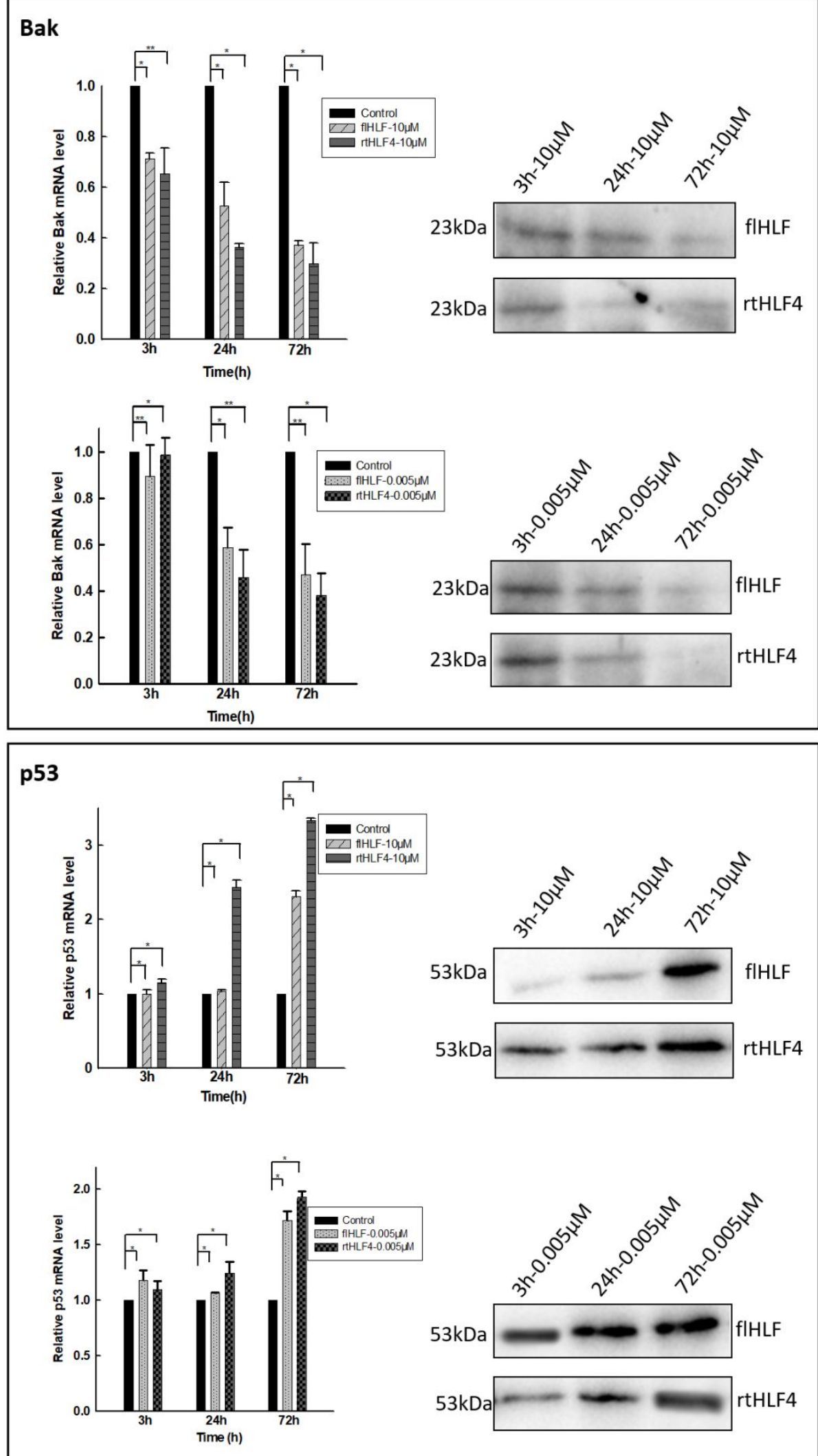

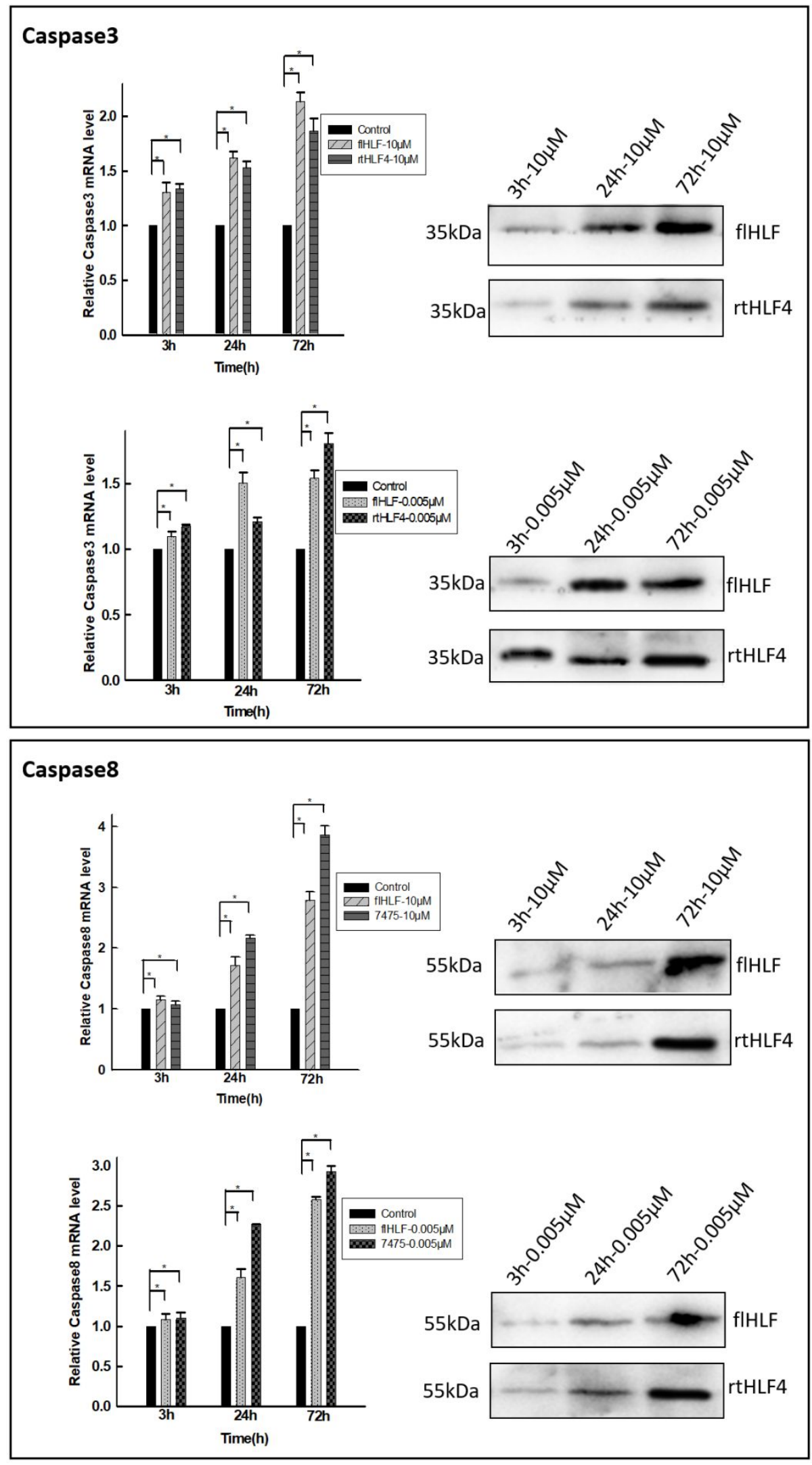

Fig S7: Full length lactoferrin and rtHLF4 with different concentration induce TAZ, GDF15, Bcl2, Bax, Bak, p53, Caspase 3 and Caspase8 gene expression and Western blot in MCF7 human breast adenocarcinoma cells. 

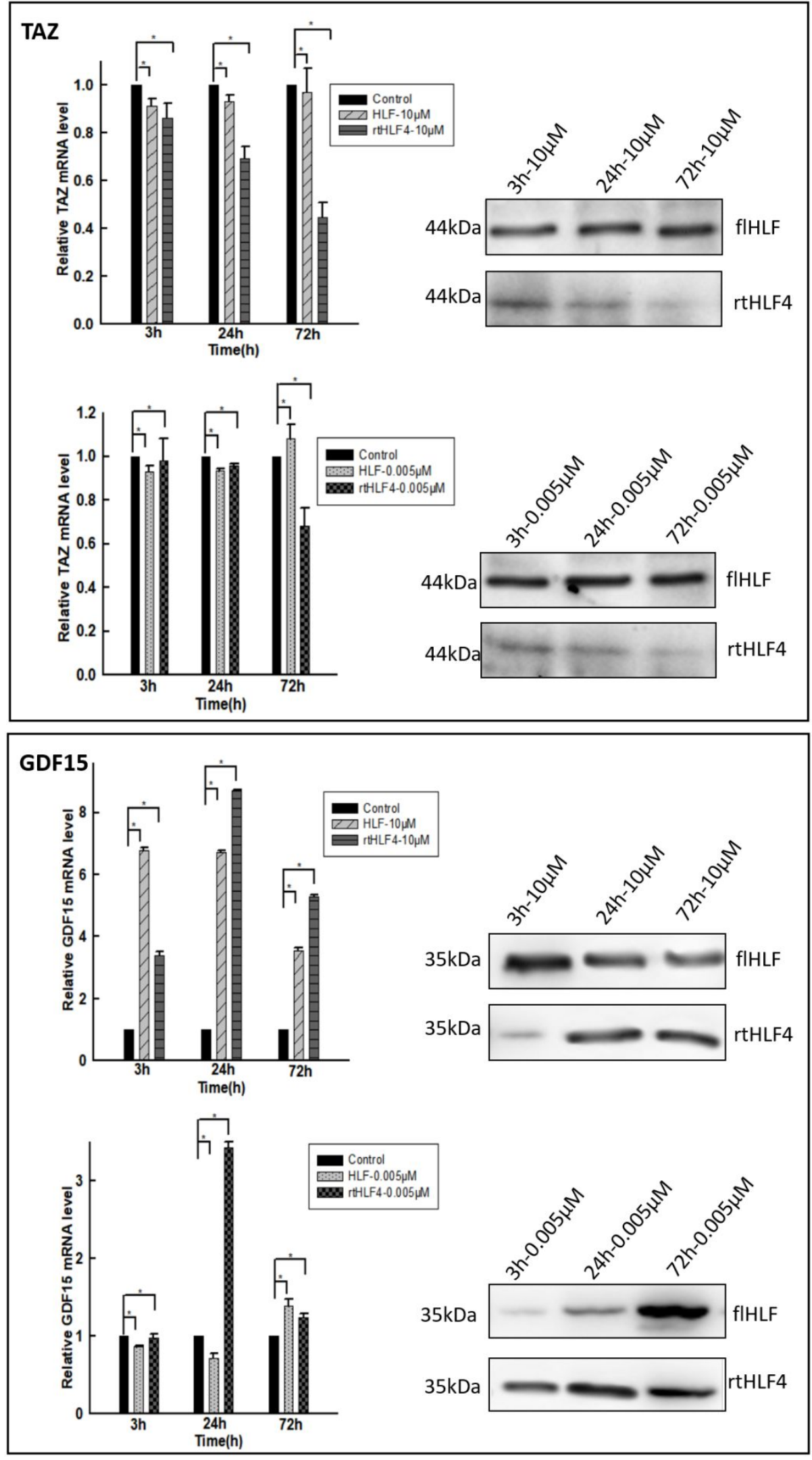

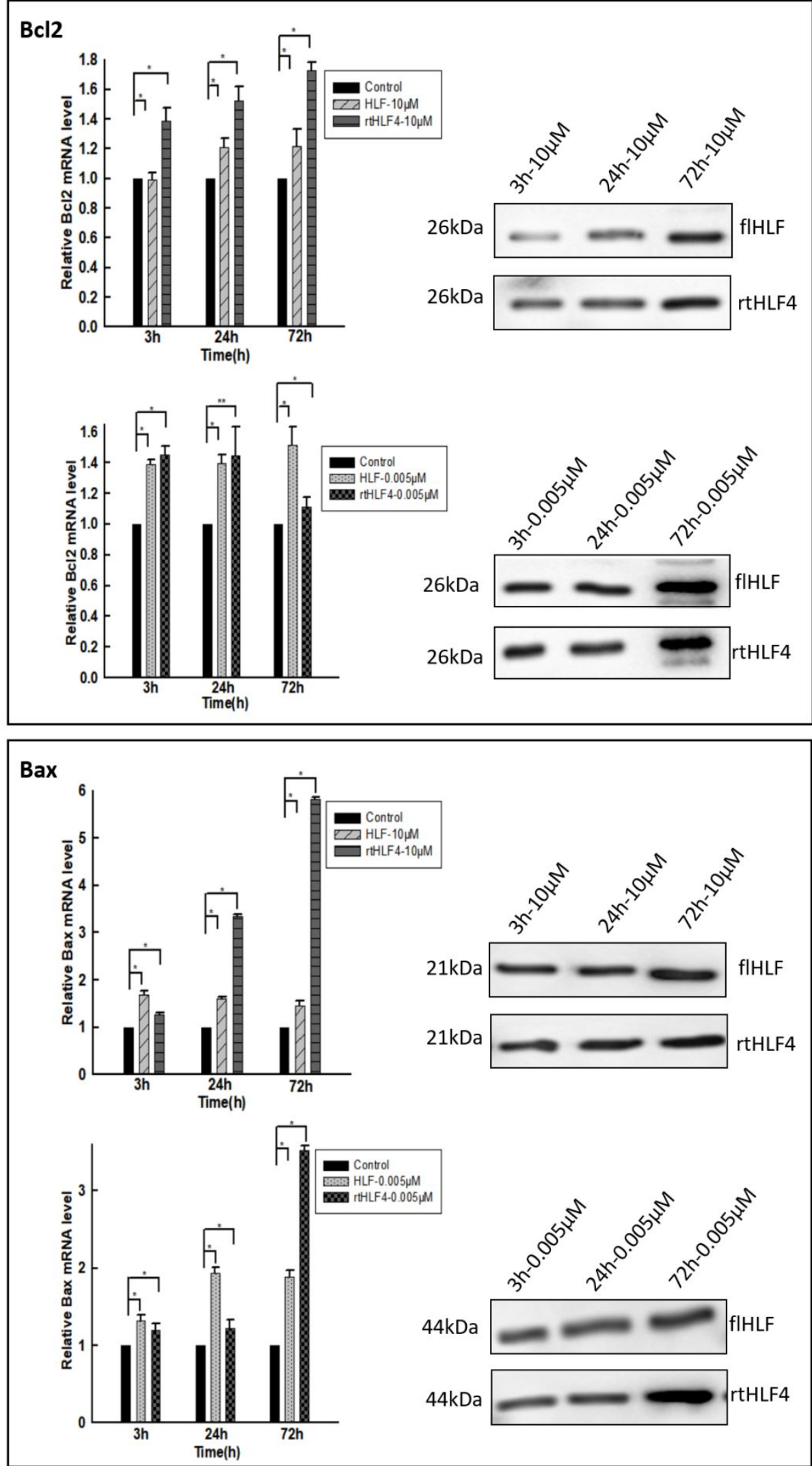

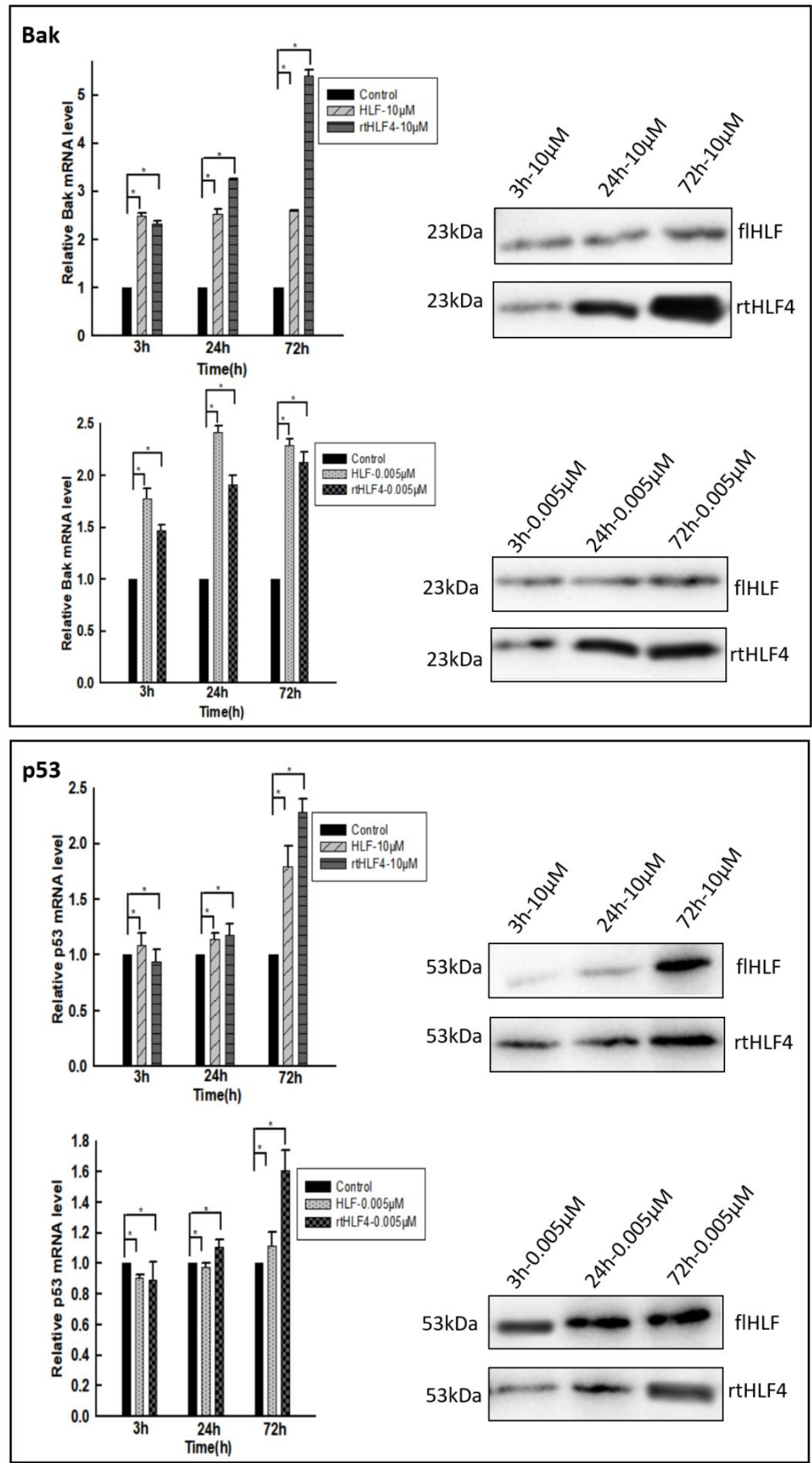

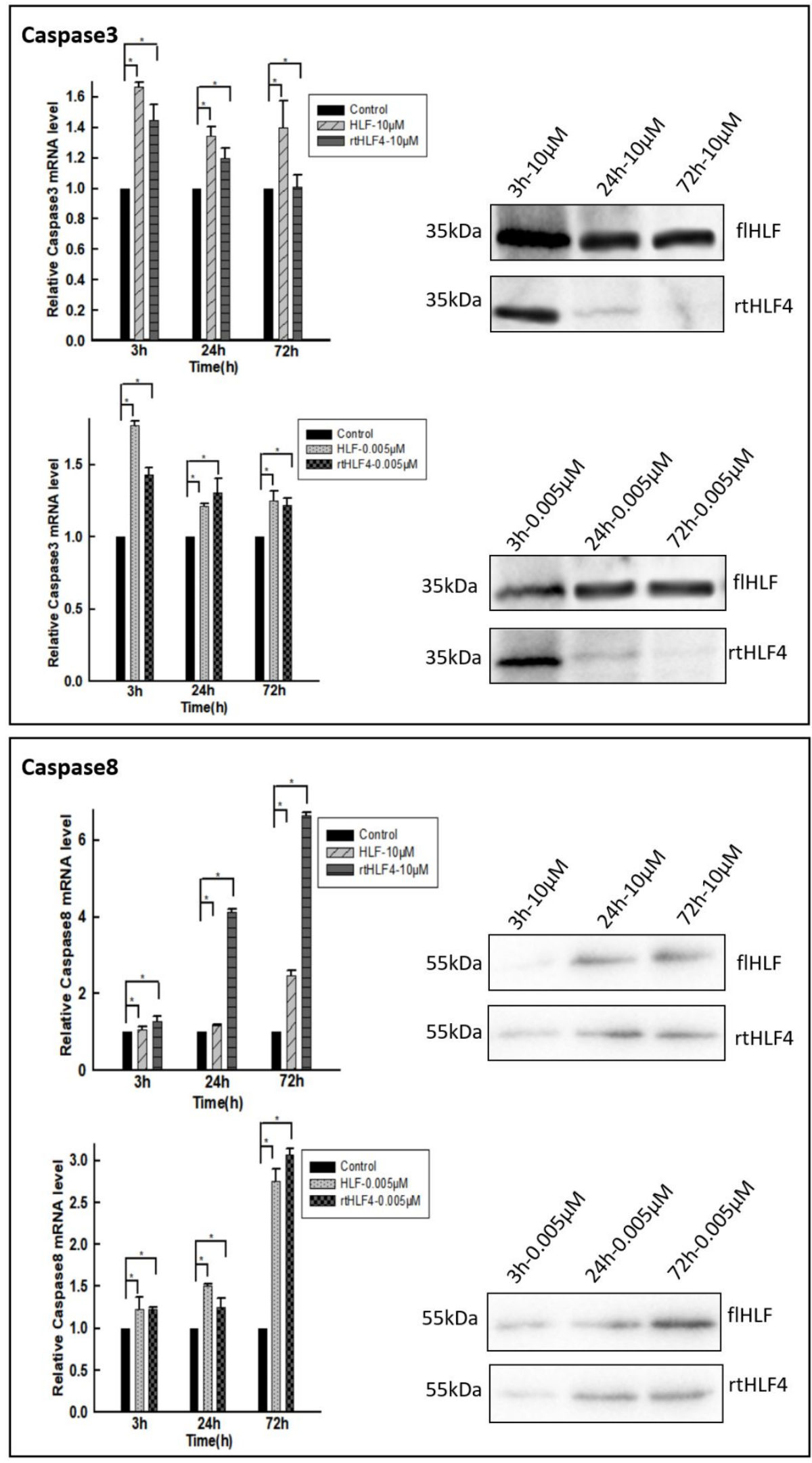

Fig S8: Full length lactoferrin and rtHLF4 with different concentration induce TAZ, GDF15, Bcl2, Bax, Bak, p53, Caspase 3 and Caspase8 gene expression and Western blot in HGC27 human gastric adenocarcinoma cells. 

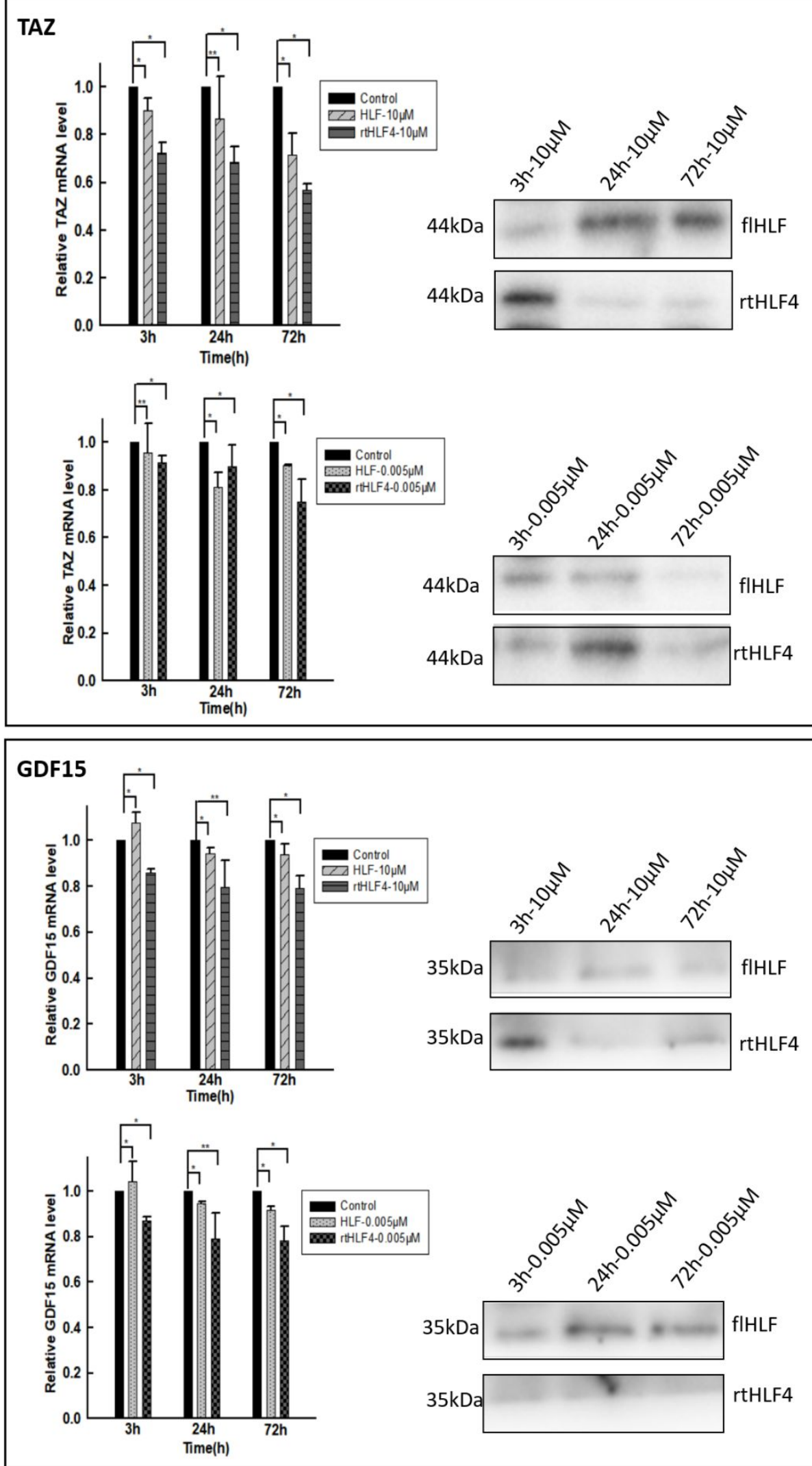

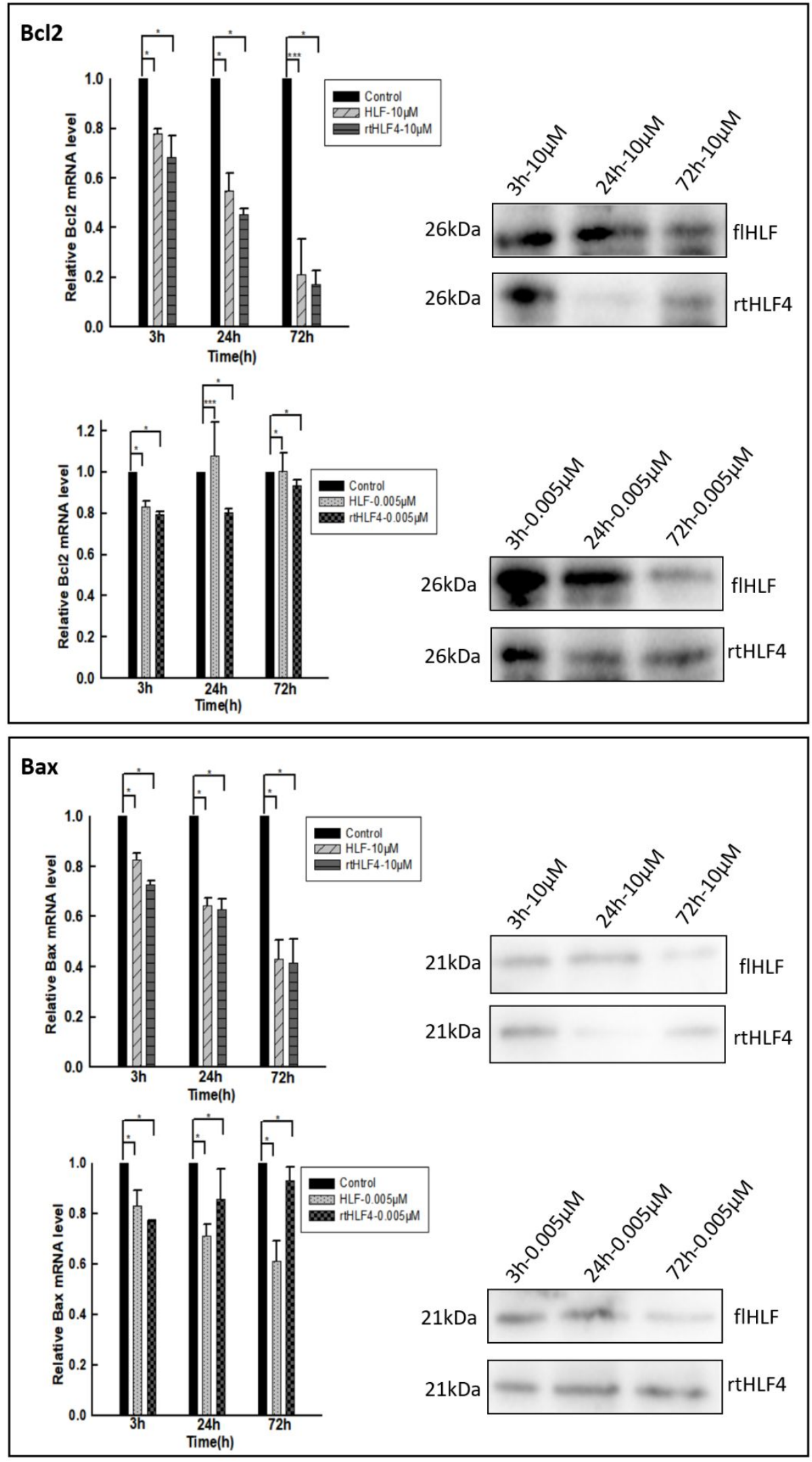

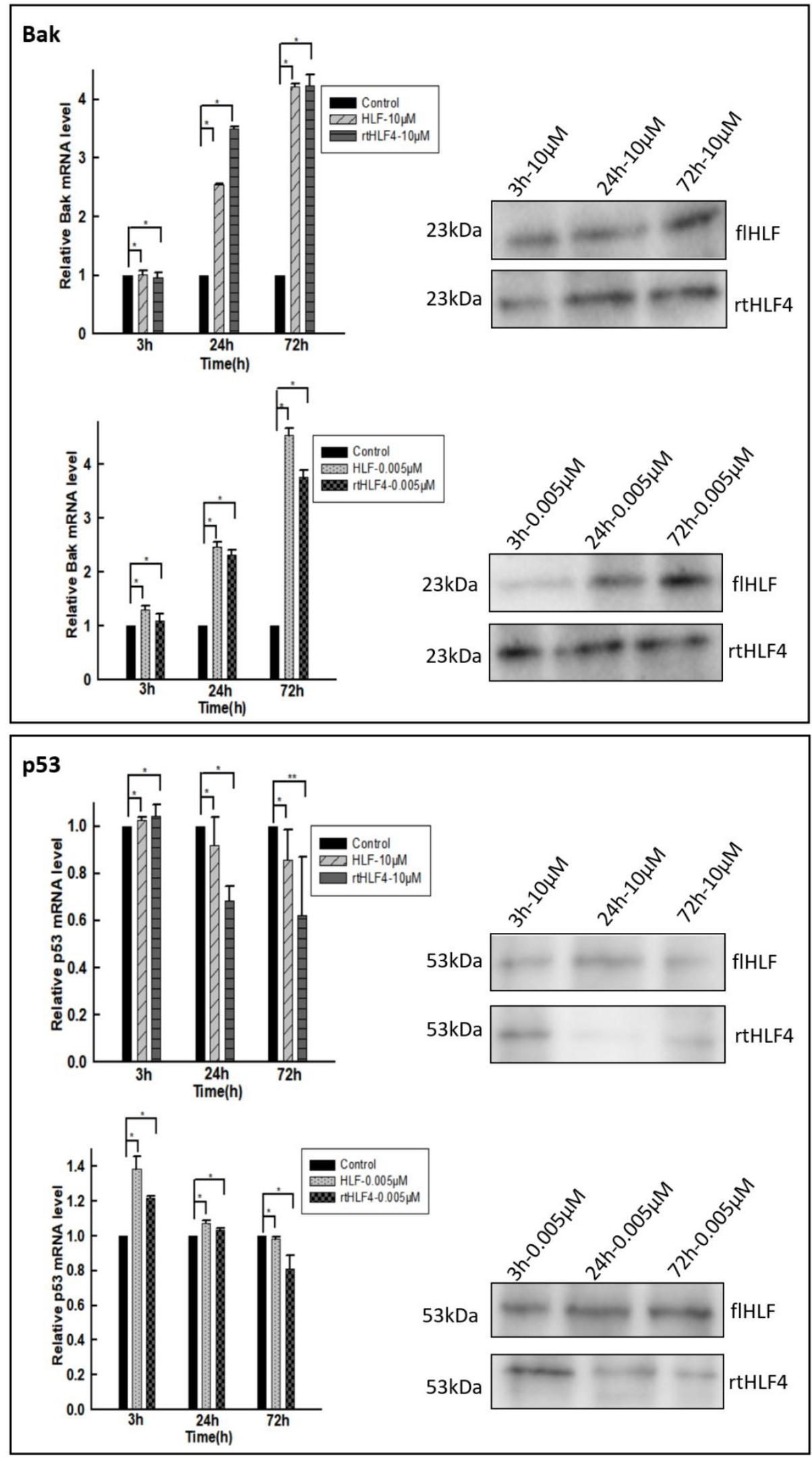

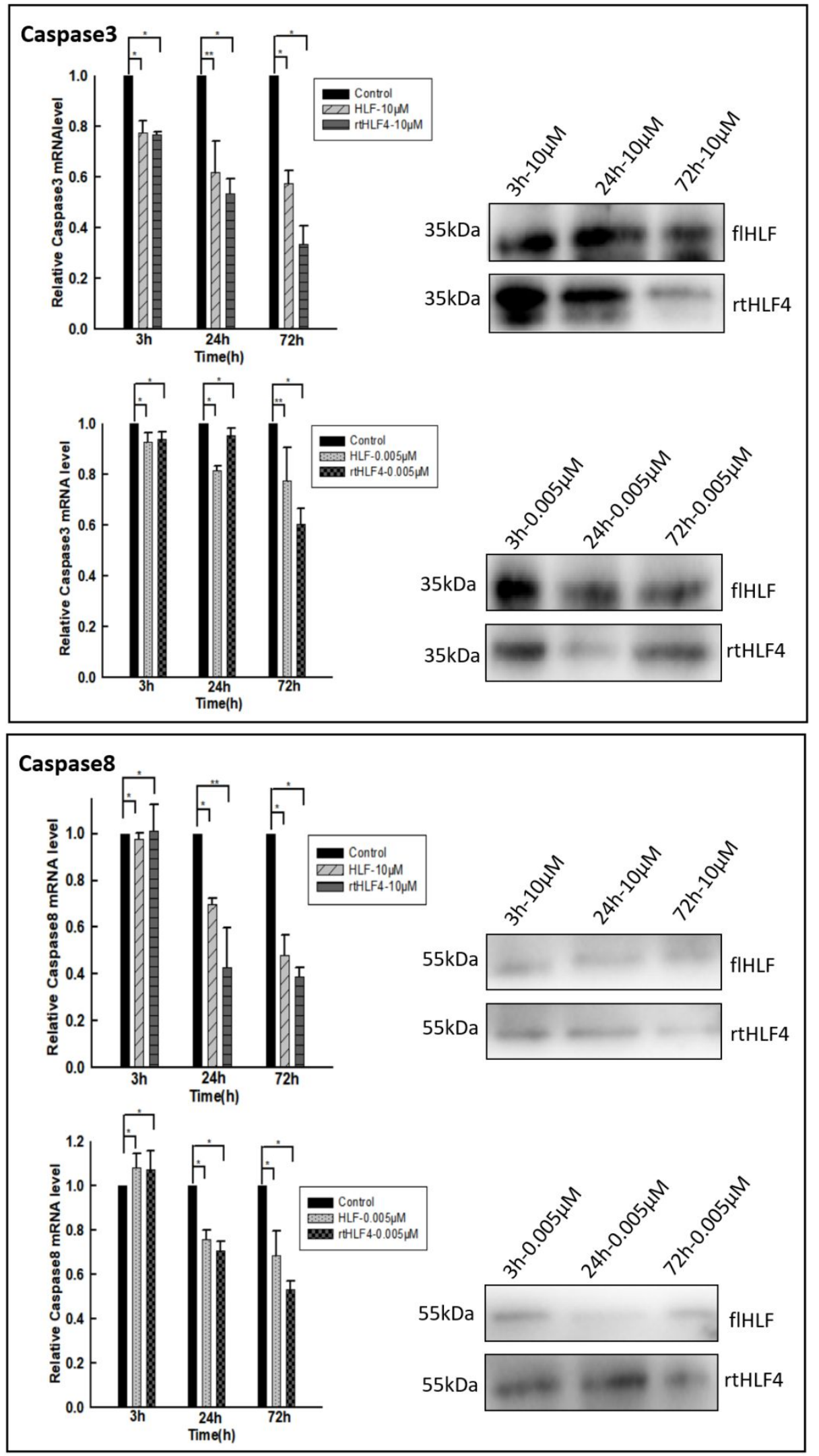

Fig S9: Full length lactoferrin and rtHLF4 with different concentration induce TAZ, GDF15, Bcl2, Bax, Bak, p53, Caspase 3 and Caspase8 gene expression and Western blot in AGS human gastric adenocarcinoma cells. 

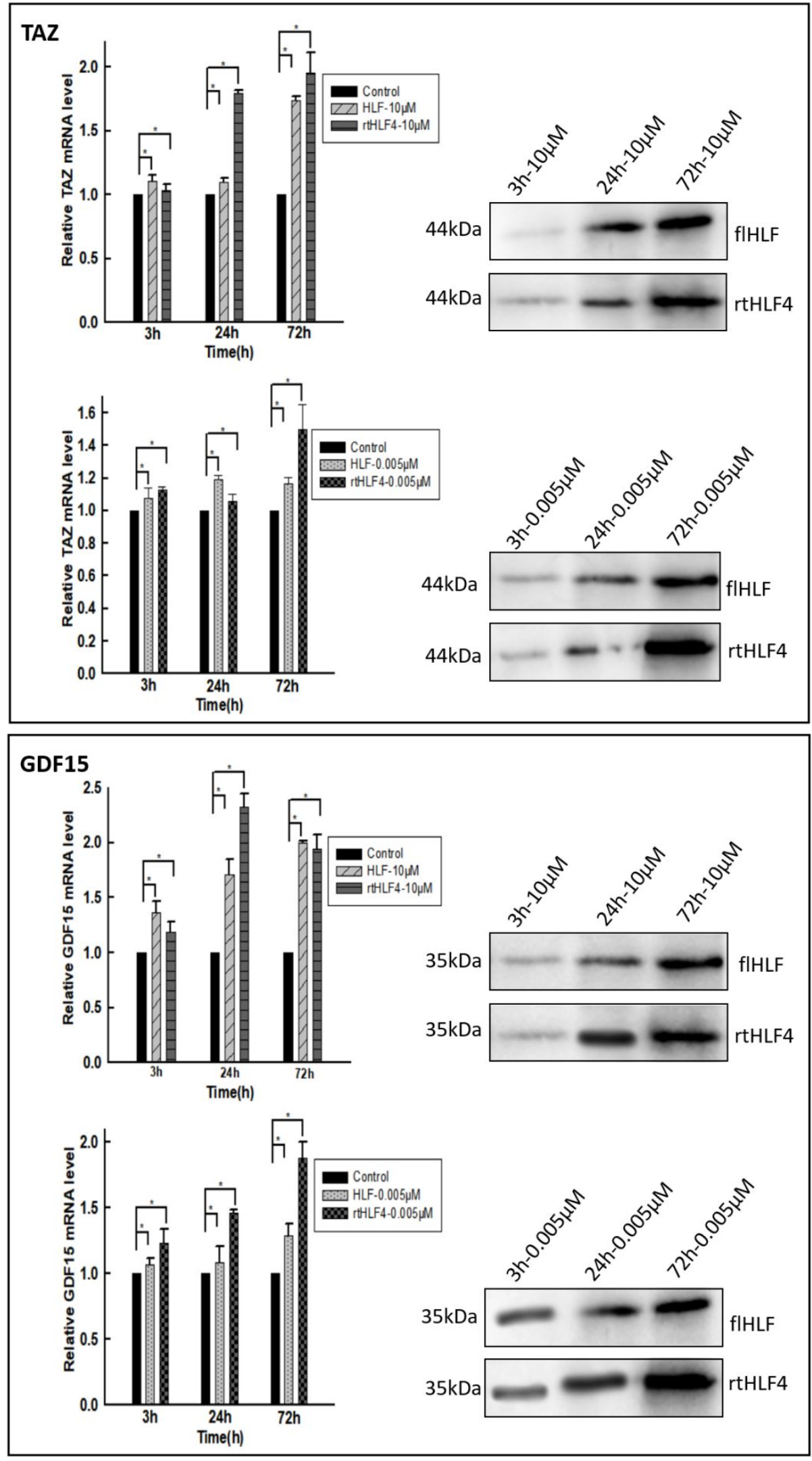

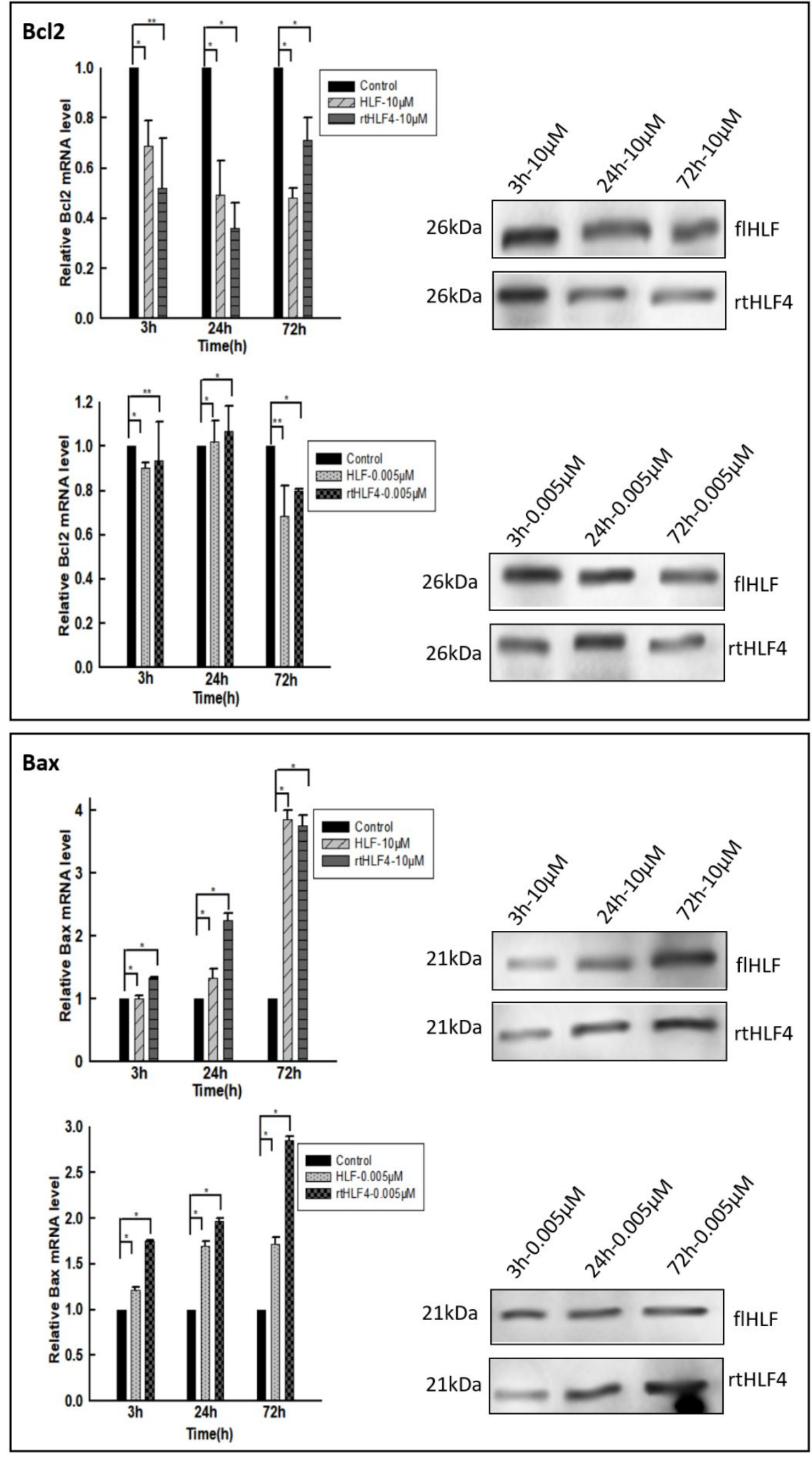

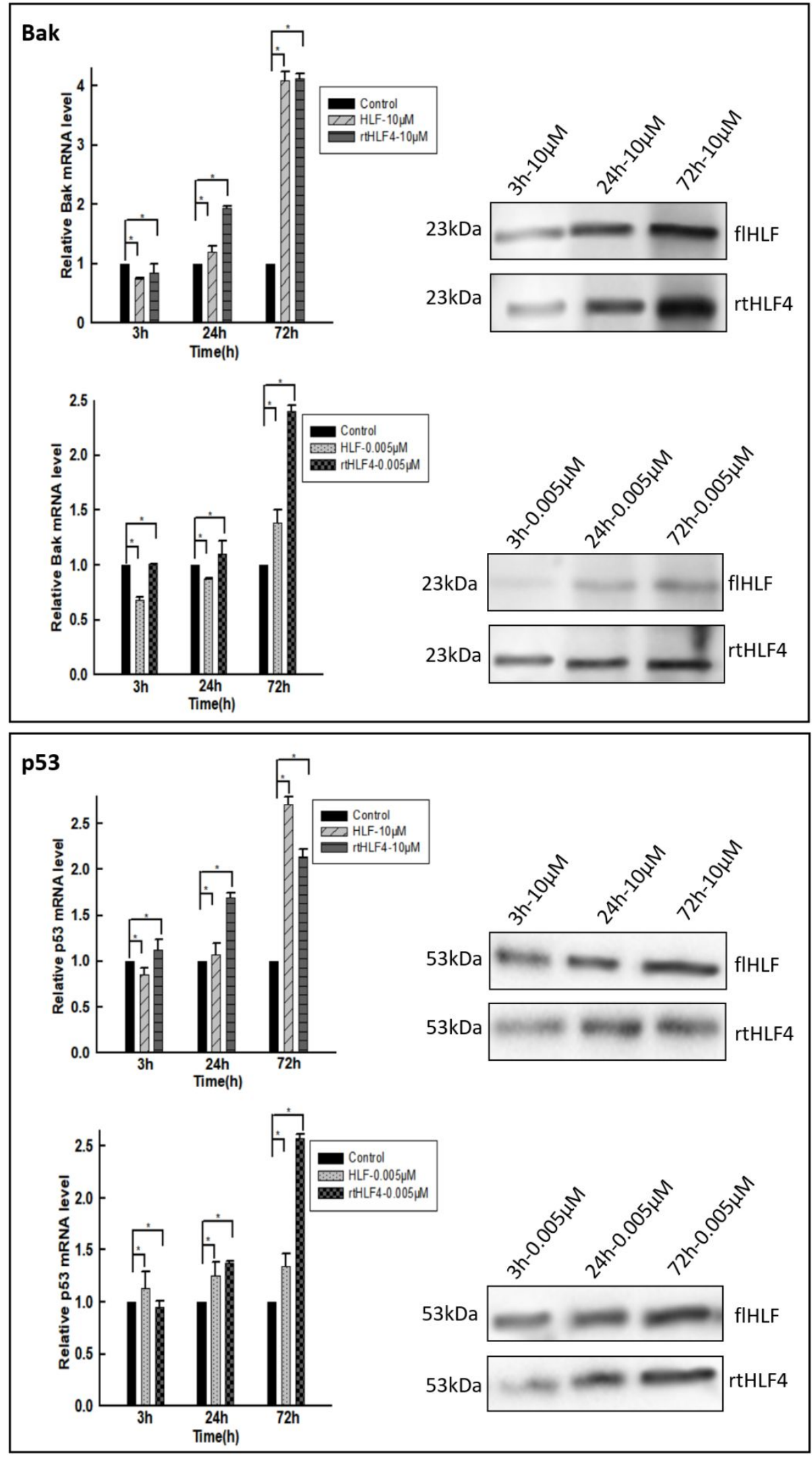

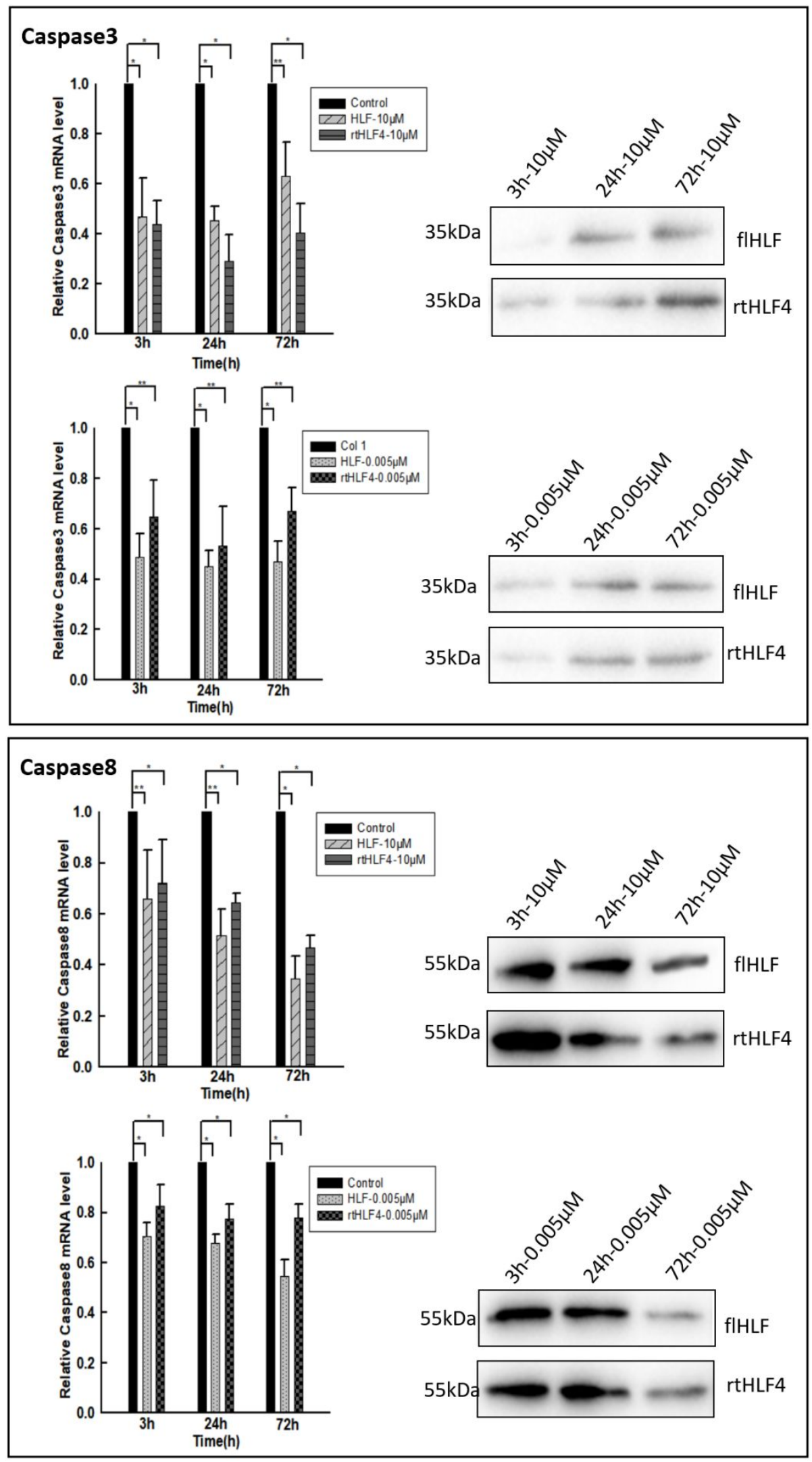

Fig S10: Full length lactoferrin and rtHLF4 with different concentration induce TAZ, GDF15, Bcl2, Bax, Bak, p53, Caspase 3 and Caspase8 gene expression and Western blot in Caco2 human colorectal adenocarcinoma cells. 

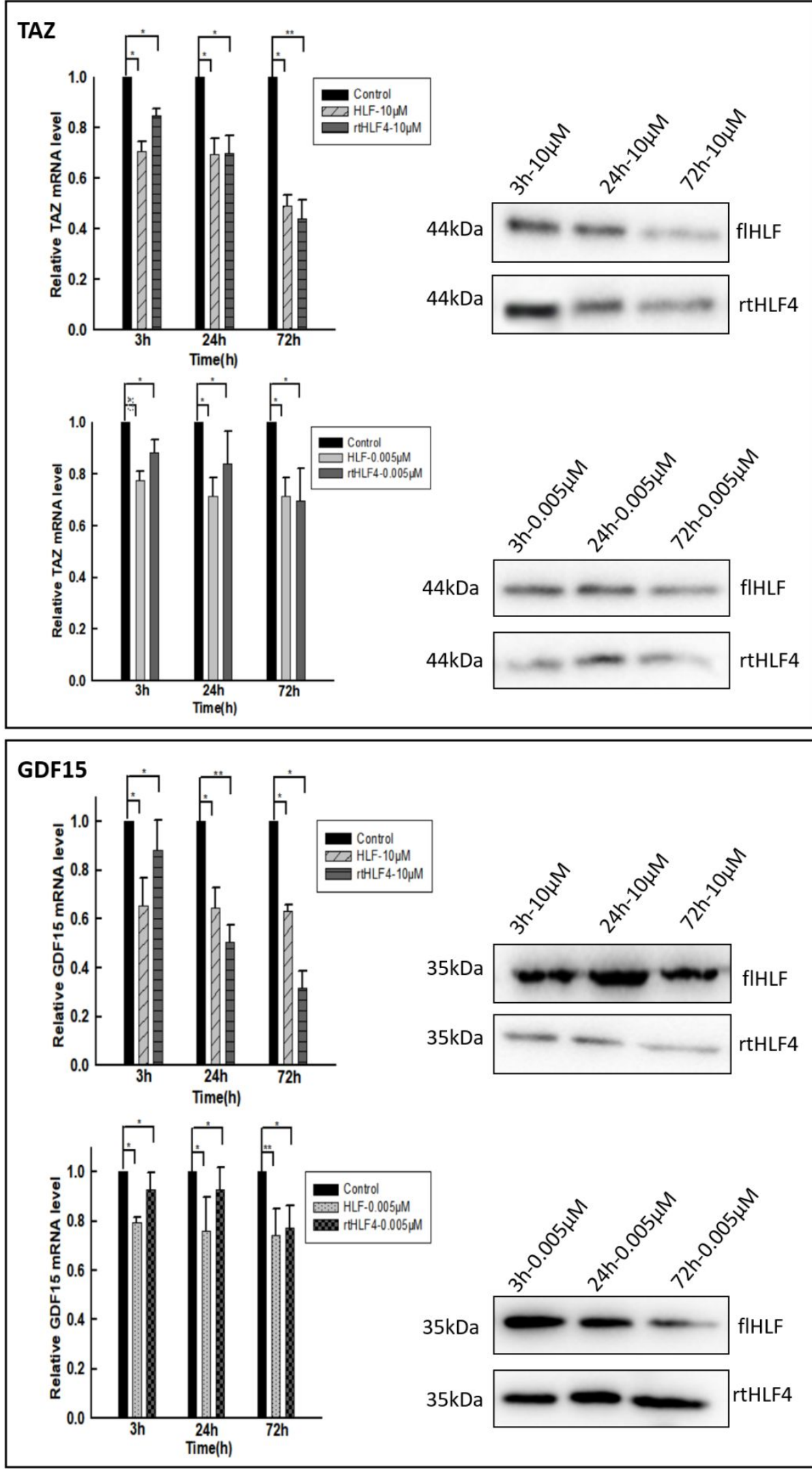

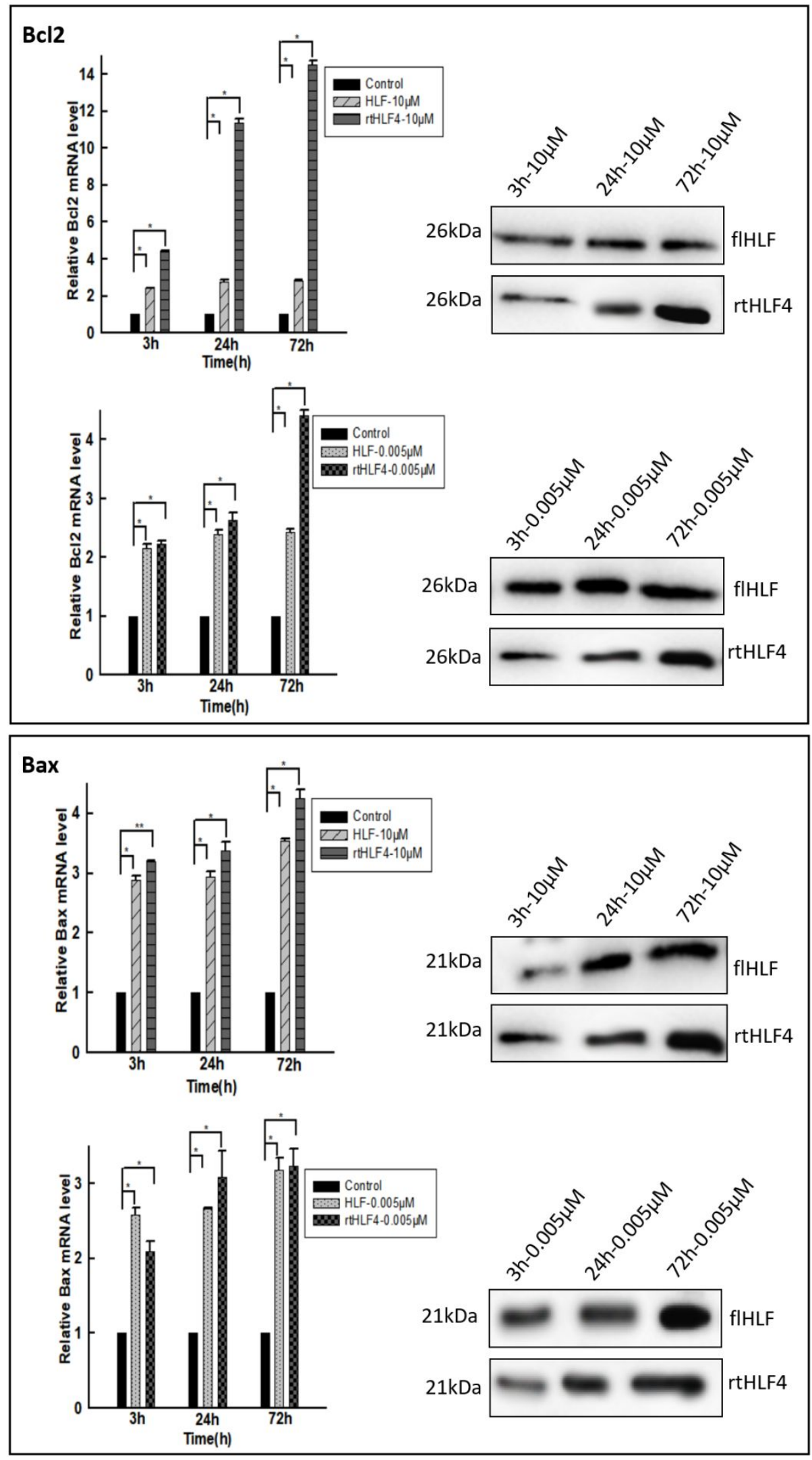

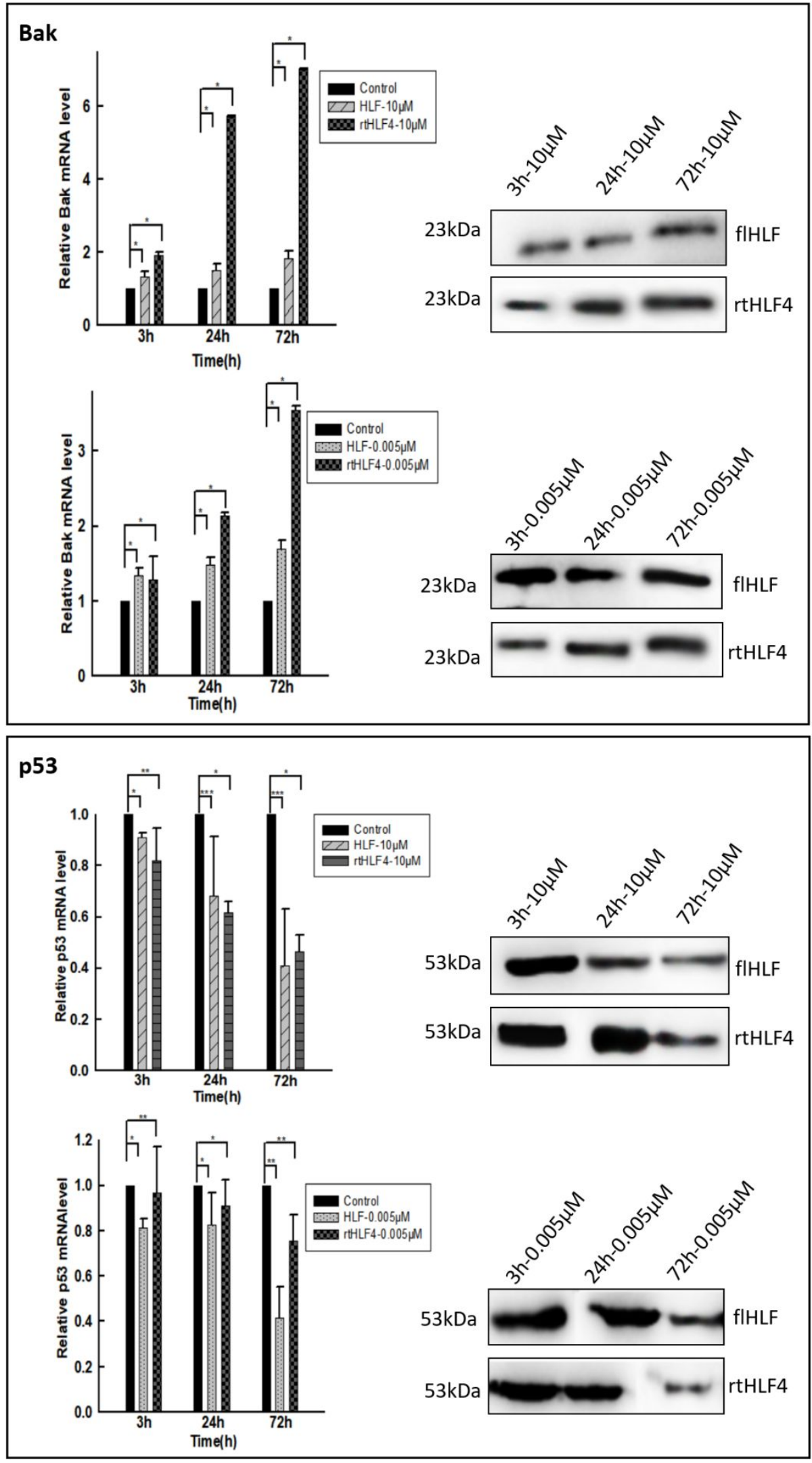

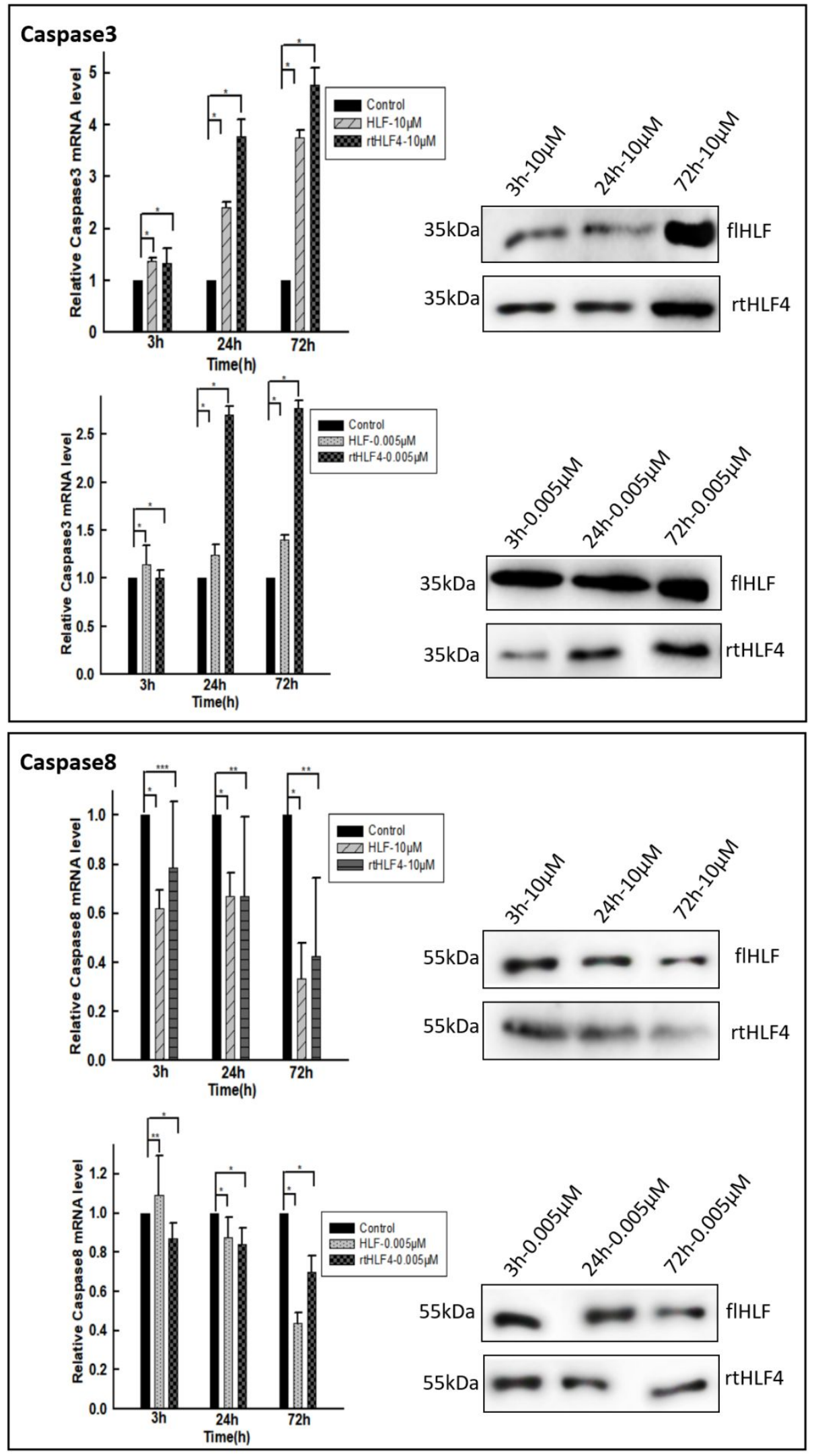

Fig S11: Full length lactoferrin and rtHLF4 with different concentration induce TAZ, GDF15, Bcl2, Bax, Bak, p53, Caspase 3 and Caspase8 gene expression and Western blot in LoVo human colorectal adenocarcinoma cells. 

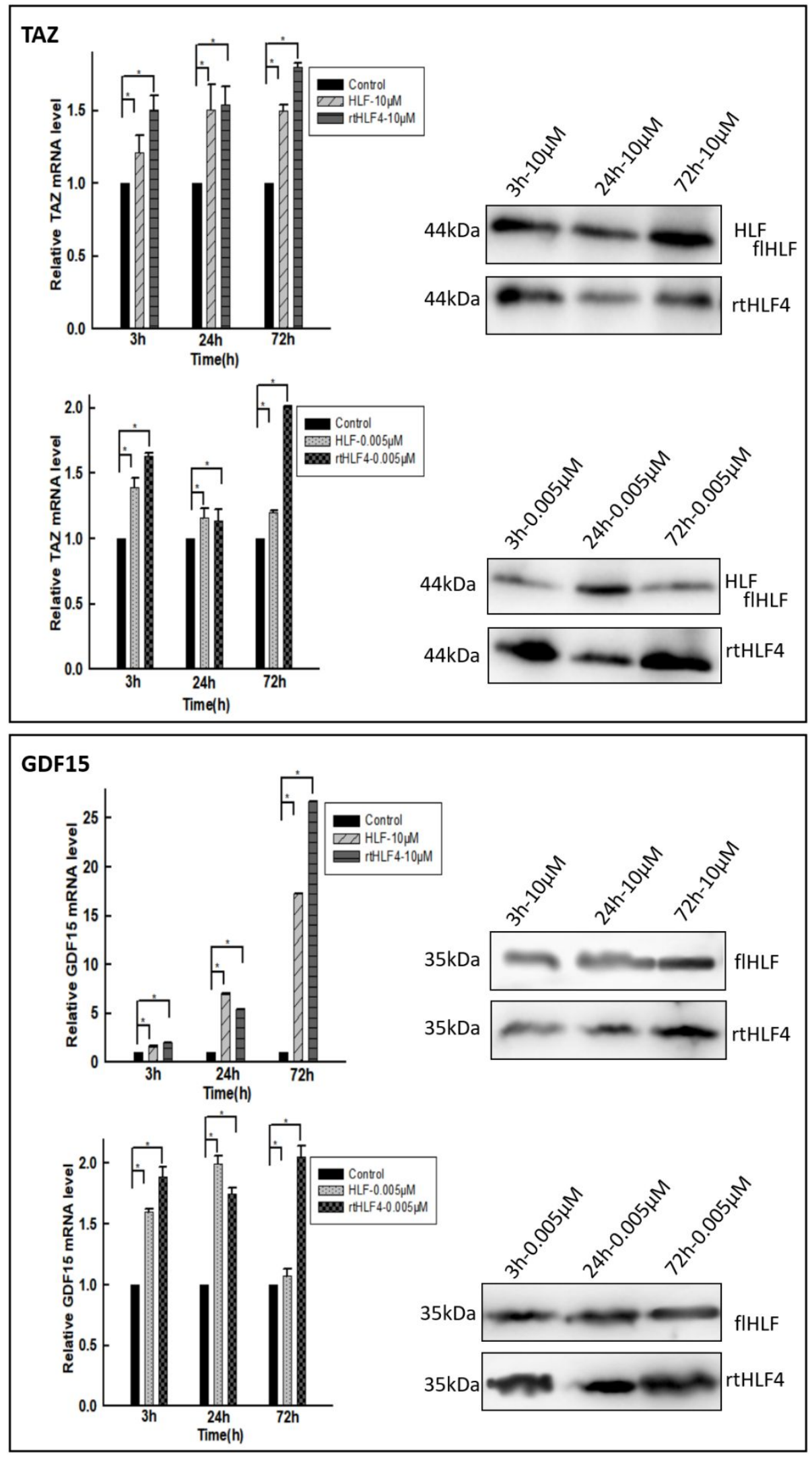

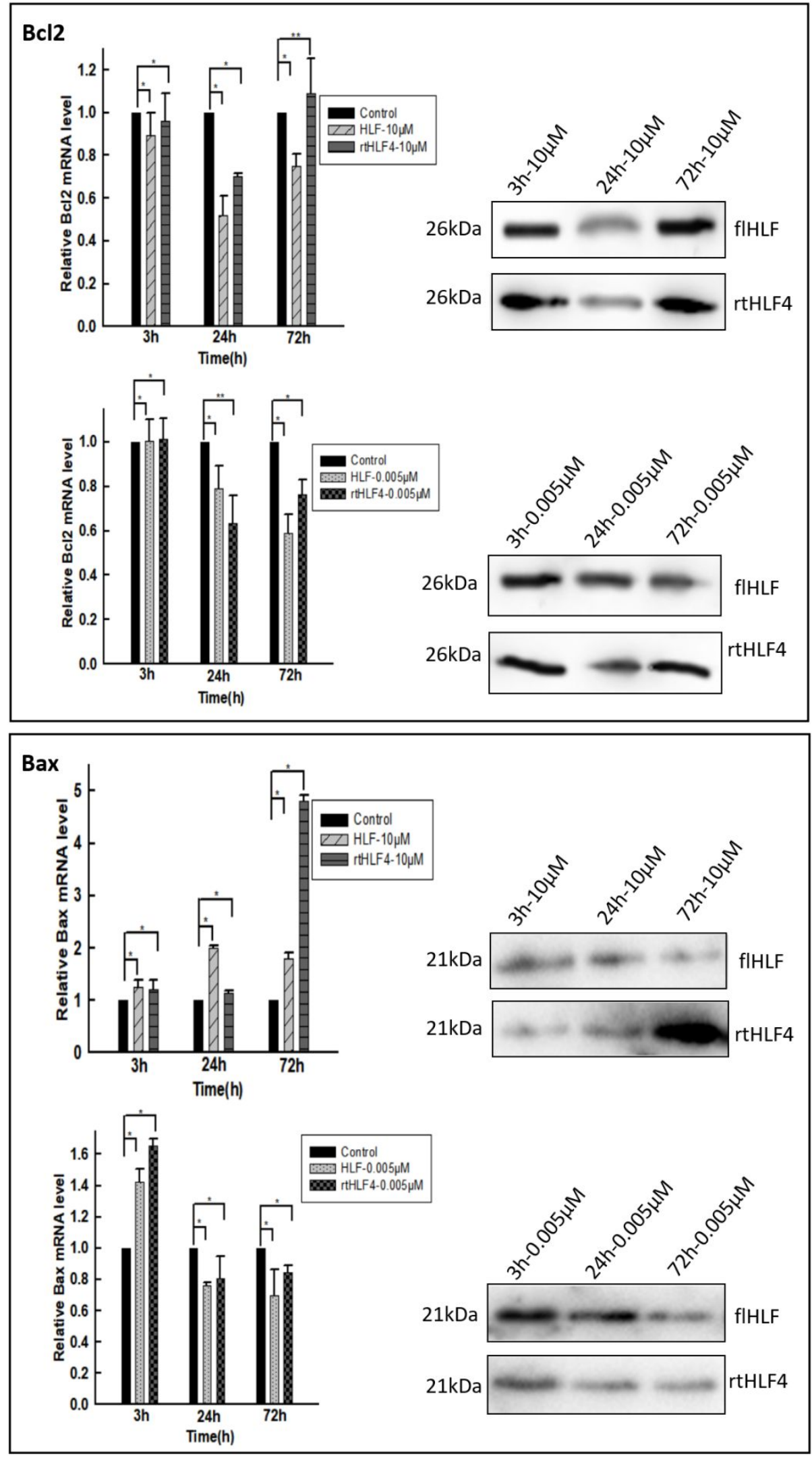

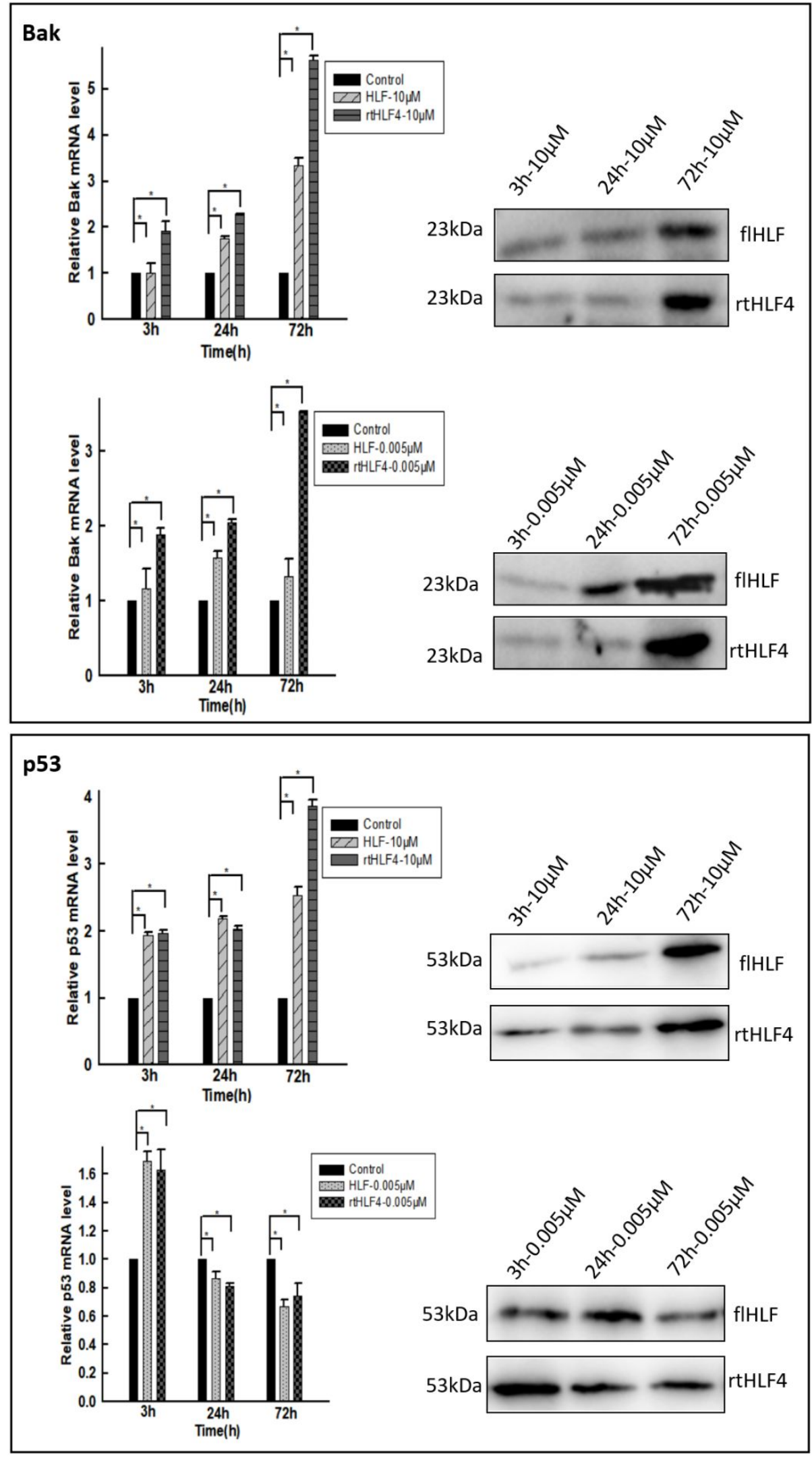

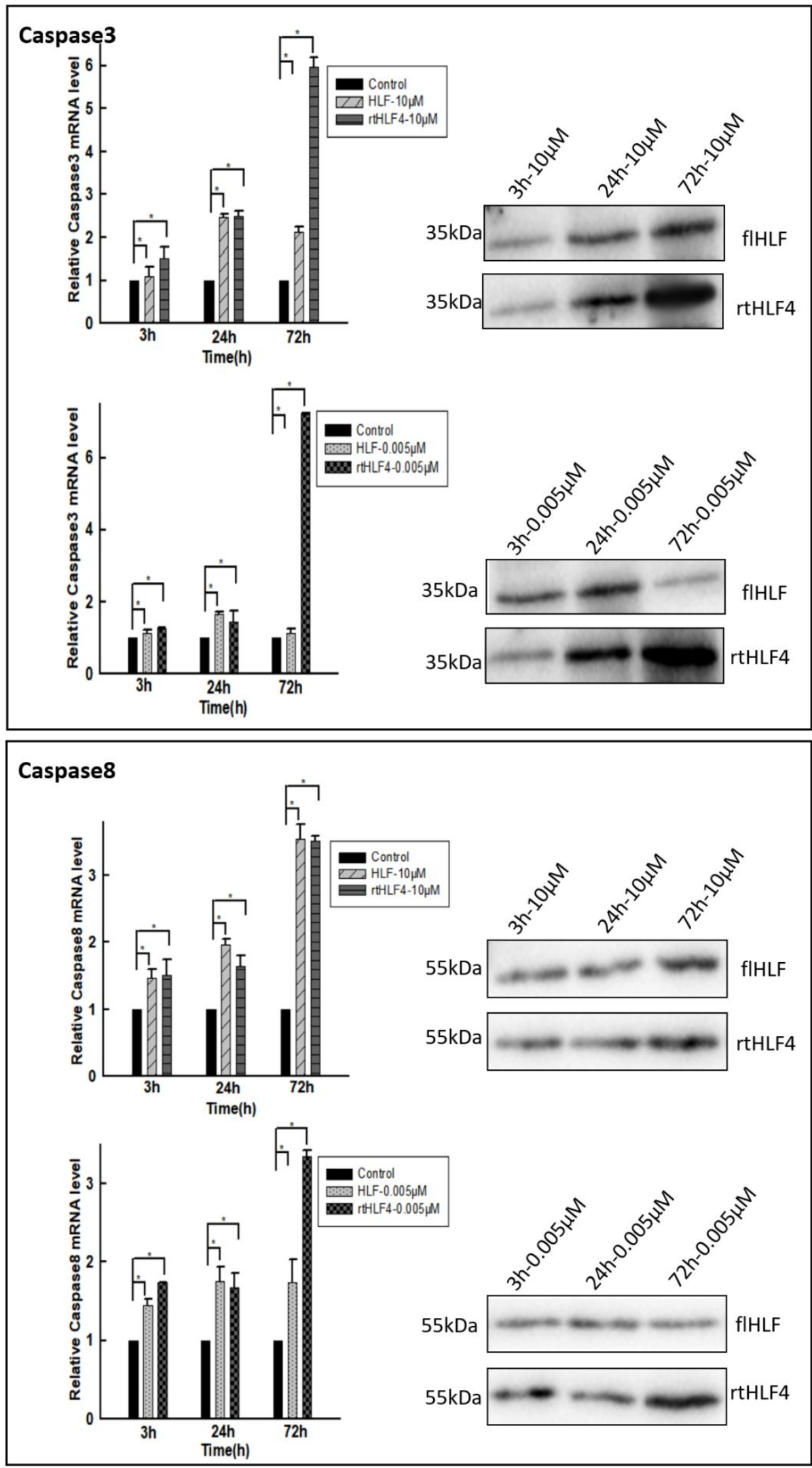

Fig S12: Full length lactoferrin and rtHLF4 with different concentration induce TAZ, GDF15, Bcl2, Bax, Bak, p53, Caspase 3 and Caspase8 gene expression and Western blot in HCT116 human colorectal adenocarcinoma cells. 